Promotion of the CIF/IFC involvement in policy dialogue at all levels

National Forest Strategy and Canada Forest Accord. $\mathrm{CIF/IFC} \mathrm{members} \mathrm{were} \mathrm{involved} \mathrm{in} \mathrm{the} \mathrm{development} \mathrm{of} \mathrm{the}$ new National Forest Strategy through attendance at regional forums and the National forum and members provided comments to the draft. The CIF/IFC signed the Canada Forest Accord in April 1998. One obligation to signing the Accord is to write an action plan on how to achieve some of the commitments in the Strategy. CIF/IFC will complete this action plan before the end of the year.

The CIF/IFC Executive once again hosted a reception during National Forest Week with Members of Parliament. Informative meetings were held with several members, and Gerry Byrne, Parliamentary Secretary to the Minister of Natural Resources - Ralph Goodale. The CIF/IFC Executive is reevaluating hosting another reception, and plan on developing a more issue related program for MPs in 1999.

CIF/IFC continued their involvement in the International Forum on Forests (IFF) and the World Commission on Forests and Sustainable Development when required. A discussion paper on CIF/IFC involvement in forest policy and international forestry issues was prepared and will be discussed at the Board of Directors meeting in Ottawa.

\section{Membership Recruitment}

A Membership task force, chaired by Evelynne Wrangler, was established following a resolution and recommendation at the 1996 and 1997 Annual general meetings. The task force developed terms of reference and met by conference call to discuss a membership retention and recruitment campaign. Recommendations will be discussed at the Board of Directors meeting in Ottawa. The "Stand and Be Recognized" brochure was updated and distributed to all the British Columbia RPFs

\section{Strategic Plan 1998-2003}

\section{History - The Last 90 Years}

In 1908, Canada was a forested land with few foresters, none of whom had graduated from a Canadian University. In 1907, the University of Toronto created a forestry department and began functioning in 1908 shortly thereafter, the University of New Brunswick and Laval University opened their doors to a forestry program. Today, eight Universities offer forestry degrees and numerous colleges offer technician/technologist programs.

Foresters in Canada met for the first time in March 1908 to organize a professional group. After much discussion, the Canadian Society of Forest Engineers (CSFE) was formed, later (1950), the name of the organization changed to the Canadian Institute of Forestry. The original membership of the CSFE was "trained foresters resident in Canada and of officials of the higher grades connected with the forest service of the Dominion and of the several provinces." Associates were "candidates connected with the practice, teaching or administration of forestry, the lumber industry or other industry dealing with wood products." Student membership was "limited to Canadian students in attendance at a school of forestry." In 1925, membership dues included receipt of the Canadian Forestry as a special voluntary dues campaign. This promotion attracted over 70 new members to the Institute. A special student package was developed and promoted at several of the schools; however, it was not very successful.

\section{Working Groups}

Through the CIF/IFC working groups several position papers were developed/revised and distributed/published over the last year: Public Participation, Global Warming and Endangered Species. Several other papers are in the development/approval stage. Working groups also hosted the technical sessions at the Ottawa Annual General meeting. The Policy and Economics Working group published a newsletter and started a discussion group on the web. We anticipate several of the other working groups will start similar initiatives. The International Working group, through CIDA financial support, supported speakers to the Prince George Annual General meeting and will do so again for the Ottawa meeting. A University lecture tour is planned in the fall of 1998 for several of the AGM International speakers.

Standing Committee on Restructuring. Second VicePresident Bruce Ferguson agreed to chair the new standing committee, which was developed following the recommendations from the 1997 Restructuring Task force. The Standing Committee members developed terms of reference for the Standing Committee and held two conference calls in 1998. A web "room" has been set up for internal discussion for the committee.

Respectively Submitted by

Roxanne Comeau, R.P.F. Executive Director

\section{Plan stratégique 1998-2003}

\section{Historique - Les 90 dernières années}

Le Canada était en 1908 un territoire forestier ayant peu de forestiers, parmi lesquels aucun n'avait gradué d'une université canadienne. En 1907, l'Université de Toronto a mis en place un programme de foresterie qui a débuté ses opérations en 1908, suivi peu après, par l'Université du Nouveau Brunswick et par l'Université Laval qui ouvrirent leurs portes à un programme de foresterie. De nos jours, huit universités offrent une formation universitaire en foresterie et plusieurs collèges dispensent des programmes de techniques ou de technologies.

Les forestiers du Canada se sont réunis une première fois en 1908 afin de former un groupe professionnel. Après plusieurs débats, la Société canadienne d'ingénieurs forestiers (SCIF) a été mise en place, puis plus tard (1950), le nom de l'organisation devint l'Institut forestier du Canada. Les membres à l'origine de la SCIF étaient "des forestiers de formation résidants au Canada ainsi que les officiers des rangs supérieurs reliés au service forestier du Dominion et de quelques provinces." Les associés étaient "les candidats rattachés à la pratique, à l'enseignement ou l'administration de la foresterie, de l'industrie du sciage ou autre industrie du secteur des produits forestiers." Les membres étudiants étaient "limités aux étudiants canadiens en formation dans une école de foresterie." En 1925, les cotisations annuelles comprenaient l'abon- 
Journal (later called the Journal of Forestry and now The Forestry Chronicle). Over the years, the membership requirements changed as has the practice of forestry. Presently, active members incorporate a broad spectrum of individuals with an interest in forests and forestry.

The CIF/IFC moved from being mainly a social organization in the early years, to providing technical information in the 20 s, to focusing on forest rehabilitation during and shortly after the wars in the 30s and 40s. The members assisted and supported the establishment of Registered Professional Forester Associations over the next 30 years and provided members with information to keep aware of forestry issues and lobbied government for change in policies to promote good forestry practices. In the 1960 s through to the 1990 s the CIF/IFC initiated a program to recognize outstanding forestry achievement of students and individuals by awarding national awards and gold medals. In 1967, the Institute expanded the University of British Columbia's silver ring program to all students graduating from a Canadian forestry undergraduate program. In 1997, over 300 students received silver rings, 26 Gold Medals were awarded to outstanding students in Colleges and Universities, and five National Awards were presented to recognize individuals' or groups' outstanding contributions to forestry and forest management practices.

All the above would not have been possible without the network of members. CIF/IFC is unique in that its members are foresters, technicians and technologists, scientists, and academics working towards the common goal of good forestry practices. The CIF/IFC sections that have formed throughout the years, 23 as of 1997, are key to keeping the membership involved. The CIF/IFC has historically, through its section meetings and the national working groups, provided technological and scientific information to its membership and the public to aid them in practicing sound forest management practices.

There are several challenges that face the Institute today, as it moves towards its $100^{\text {th }}$ anniversary. The external environment is changing and will change, and CIF/IFC needs to develop strategies that are responsive to these changes. In doing so, the Institute strengthens its effectiveness and will grow. The $\mathrm{CIF/IFC} \mathrm{needs} \mathrm{to} \mathrm{achieve} \mathrm{the} \mathrm{best} \mathrm{fit} \mathrm{between} \mathrm{its} \mathrm{members,} \mathrm{the}$ organization and the environment while giving the Institute and its members focus and direction. Some of the key challenges are:

1. To keep current with the forestry technological advancements and sustainable forest management practices within Canada and globally and to communicate the advancements and practices to members, politicians, and the public.

2. To involve membership in promoting good forest management practices, and to encourage the membership to continue to network within Canada and internationally.

3. To provide leadership in forestry by promoting the best practices known nationally and internationally.

\section{CIF/IFC Strategic Plan 1998-2003}

This document presents the CIF/IFC Mission Statement, Values and Beliefs and the Objectives of the Institute as well as a Strategic Plan. The plan incorporates the 1997 transition year and presents implementation schedules that have been developed by a core task force with section and member input. The CIF/IFC Values and Beliefs with the CIF/IFC Objects form nement au Canadian Forestry Journal (par la suite dénommé le Journal of Forestry et de nos jours, le Forestry Chronicle). Au cours des années, les prérequis à l'adhésion changèrent comme a changé la pratique de la foresterie. Actuellement, les membres actifs regroupent un large éventail d'individus intéressés par les forêts et la foresterie.

Le CIF/IFC a évolué d'une organisation sociale principalement à ses débuts, pour dispenser de l'information technique dans les années 20, puis pour se concentrer sur la reforestation au cours et peu après les guerres dans les années 30 et 40 . Les membres ont participé et ont appuyé la mise en place d'association de forestiers professionnels inscrits au cours des 30 années suivantes et permirent à leurs confrères de demeurer sensibilisés face aux enjeux forestiers, tout en effectuant des démarches auprès du gouvernement pour modifier les politiques pour de meilleures pratiques forestières. Depuis les années 60 jusqu'à ce jour, l'Institut a mis en place un programme pour reconnaître les contributions remarquables en foresterie de la part des étudiants et des individus en remettant des prix nationaux et des médailles d'or. En 1967, l'Institut a étendu le programme de joncs d'argent de l'Université de la Colombie-Britannique à tous les étudiants gradués d'un programme canadien de baccalauréat en foresterie. En 1997, plus de 300 étudiants ont reçu leur jonc d'argent, 26 médailles d'or furent remises à des étudiants reconnus pour leurs résultats académiques et leur implication dans leur milieu collégial ou universitaire, et cinq prix nationaux furent décernés pour souligner la contribution exceptionnelle d'un individu ou d'un groupe en foresterie et dans la pratique de l'aménagement forestier.

Tout ce qui a été mentionné ci-dessus n'aurait été possible sans le réseau établi par les membres. L'Institut est unique du fait que ses membres sont des forestiers, des techniciens et des technologistes, des chercheurs, des universitaires oeuvrant pour atteindre un but commun portant sur de saines pratiques forestières. Les sections de l'Institut qui ont été formées au cours des années, soit 23 en 1997, sont la clé de la participation des membres. L'Institut a transmis, et l'histoire le prouve, par l'entremise des activités de ses sections et ses groupes de travail nationaux, l'information technique et scientifique à ses membres et au public afin de les aider à appliquer de saines pratiques d'aménagement forestier.

L'Institut fait face à plusieurs défis de nos jours, alors qu'il se dirige vers son 100e anniversaire. L'environnement externe est en changement et demeurera changeant, et l'Institut doit élaborer des stratégies qui peuvent répondre à ces changements. En faisant de la sorte, l'Institut renforce son efficacité et pourra continuer de croître. L'Institut doit rechercher la meilleure adéquation entre ses membres, l'organisation et son environnement tout en donnant à l'Institut et à ses membres un but à atteindre et une direction à suivre. Certains des principaux défis sont:

1. Se maintenir à jour avec les progrès technologiques en foresterie et les pratiques d'aménagement forestier durable au Canada et dans le monde, et communiquer ces progrès et ces pratiques aux membres, aux politiciens et au public.

2. Faire participer les membres à la promotion des saines pratiques d'aménagement forestier, et à encourager les membres à étendre le réseau de contacts au Canada et sur la scène internationale.

3. Assumer un leadership en foresterie par la promotion des meilleures pratiques reconnues à l'échelle nationale et internationale.

\section{Le plan stratégique du CIF/IFC 1998-2003}

Ce document présente l'énoncé de la mission de l'Institut, ses valeurs, ses croyances et ses objectifs ainsi que son plan 
the framework for the Strategic Plan, plus two additional elements focusing on the financial security and the organizational function aid in contributing a strong foundation to the Institute. A Communication Plan has been developed as a separate document to focus solely on the Institutes' communication. Many of the activities within this Strategic Plan dovetail with the Communication plan or refer to the Communication plan. An implementation schedule has been developed and is available from National office.

The National Board of Directors priortized the activities within the Strategic plan during their 1998 Board of Directors meeting in Ottawa, Ontario. These priorities will guide the Institute's activities over the next few years.

\section{Mission}

The Mission of the CIF/IFC is to advance the stewardship of Canada's forest resources, provide national leadership in forestry, promote competence among forestry professionals, and foster public awareness of Canadian and international forestry issues.

\section{Objects}

The specific objects of the Institute as stated in the By-Laws are:

1. To provide leadership in all aspects of forestry ${ }^{1}$ in Canada.

2. To foster public understanding of forestry, and its importance to Canada.

3. To advance members in their knowledge of forestry.

4. To cultivate an esprit de corps among members.

5. To publish a professional and scientific forestry journal.

6 . To recognize through a national awards program the outstanding contributions made to forestry by members and non-members.

7. To recognize and welcome to the profession, graduates from Canadian University forestry schools through the presentation of forestry rings.

8. To cooperate with other organizations having similar objectives.

\section{Values and Beliefs}

We believe that members of the Canadian Institute of Forestry/Institut forestier du Canada (CIF/IFC) should have an intimate knowledge and understanding of Canada's forests.

We believe that the stewardship of our forests must be based on an understanding of ecological principles coupled with appropriate inventory and monitoring to ensure that the criteria of ecological integrity and function are maintained within an acceptable sociological framework.

Through this understanding, members should promote the intelligent use of Canada's forests to provide a sustainable flow of a wide range of forest commodities, representing a balance of economic, spiritual, recreational and wildlife habitat values.

A wide range of forest alternatives is possible ranging from natural forests to intensively managed tree farms. We believe that the mix of forest uses required to satisfy Canadian needs

\footnotetext{
${ }^{1}$ Forestry: the science, the art and the practice of managing on a sustainable basis the ecosystems that occur on or in association with forest lands, for environmental, economic, social and cultural values.
}

stratégique. Le plan comprend l'année de transition 1997 et présente un calendrier d'implantation qui a été élaboré par un groupe de travail qui a regroupé les intrants des sections et des membres. Les valeurs et les croyances de l'Institut ainsi que ses objectifs constituent le cadre de travail du plan stratégique, ainsi que deux éléments additionnels centrés sur la sécurité financière et la fonction organisationnelle qui participent à l'élaboration d'une solide ossature structurelle. Un plan de communication a été élaboré sous forme de document séparé centré seulement sur les communications de l'Institut. Plusieurs des activités de ce plan stratégique se raccordent ou font référence au plan de communication. Un calendrier d'implantation a été élaboré et est disponible auprès du bureau national.

Le conseil national d'administration a identifié prioritairement les activités du plan stratégique au cours de la réunion du conseil d'administration de 1998 qui a eu lieu à Ottawa, en Ontario. Ces priorités guideront les activités de l'Institut au cours des prochaines années.

\section{Mission}

La mission de l'Institut vise à faire progresser l'intendance des ressources forestières du Canada, à assumer un leadership national en foresterie, à promouvoir la compétence parmi les professionnels de la foresterie et à stimuler la sensibilisation du public sur les enjeux forestiers canadiens et internationaux.

\section{Buts}

Les buts spécifiques de l'Institut tel que décrits dans les Règlements sont:

1. Assumer un leadership dans tous les aspects de la foresterie ${ }^{1}$ au Canada.

2. Stimuler la compréhension par le public relativement à la foresterie et à son importance au Canada.

3. Faire progresser parmi ses membres les connaissances reliées à la foresterie.

4. Cultiver un esprit de corps parmi les membres.

5. Publier une revue forestière professionnelle et scientifique.

6. Souligner par l'entremise d'un programme national de prix les contributions remarquables réalisées en foresterie par ses membres et les non membres.

7. Souligner et accueillir au sein de la profession, les gradués de écoles de foresterie des universités canadiennes par une remise de joncs de forestier.

8. Coopérer avec d'autres organisations ayant des objectifs similaires.

\section{Valeurs et Croyances}

Nous estimons que les membres du Canadian Institute of Forestry/Institut forestier du Canada (CIF/FC) devraient avoir une connaissance et une compréhension globale des forêts canadiennes.

Nous estimons que l'intendance de nos forêts doit reposer sur la compréhension des principes écologiques associée à un inventaire et une surveillance appropriés pour assurer que les critères de l'intégrité et de la fonction écologiques sont maintenus à l'intérieur d'un cadre sociologique acceptable.

Grâce à cette compréhension, les membres devraient promouvoir l'utilisation intelligente des forêts canadiennes dans le but de procurer un flot durable d'un large éventail de produits forestiers de base, en équilibre avec les valeurs économiques, spirituelles, et récréatives et les habitats fauniques.

\footnotetext{
${ }^{1}$ Foresterie: La science, l'art et la pratique de l'aménagement sur une base durable des écosystèmes qui se retrouvent sur ou en association avec les terres forestières, à des fins environnementales, économiques, sociales et culturelles.
} 
should be based on an informed public dialogue. Our members should play a constructive role in facilitating such debate.

\section{(Adopted at the 1996 CIF/IFC Annual General meeting, minor revisions in 1997.)}

\section{CIF/IFC Organization Structure}

In accordance with the by-laws, rules and regulations of the CIF/IFC the organization structure consists of a Board of Directors, Executive Committee, Executive Director, Forestry Chronicle Team, Sections, National Committees and Board and Working Groups.

The Board of Directors includes one representative from each Section, together with members of the Executive committee. The Board is responsible for managing the business of the Institute. The Section councils and members annually appoint a representative to the CIF/IFC National Board of Directors.

The Executive Committee guides, directs and otherwise assists the Executive Director in conducting the affairs of the Institute. They are:

President - the Chief Executive Officer of the Institute.

Past President

First Vice-President

Second Vice-President

The Executive Committee is elected by the membership. Annually nominations for Second and First Vice-President are requested, and if required a ballot vote by membership is held. The First Vice-President automatically assumes the position of President, and the President automatically assumes the role of Past-President.

The Executive Director, a full-time salaried employee of the Institute, is responsible for the day-to-day operation of the Institute and for managing the Head Office, located in Ottawa.

The Forestry Chronicle is administered by an editorial team comprised of an editor, research editor, production manager and the Executive Director. The Chronicle advertising is administered in house through CIF/IFC staff.

Sections may be formed through application by at least fifty voting members or by resolution through the Board of Directors. Currently there are 23 sections. The Sections form the "grassroots" operation of the organization, are volunteer-run for the most part, and are the direct link to the membership.

\section{National Committees and Boards \\ Finance Committee}

Appointed by the Executive Committee. This committee oversees the financial status of the Institute and assists the Executive Director in preparing the annual budget for member approval at the Annual General meeting.

\section{Awards Committee}

Comprised of the Executive Committee, chaired by the CIF/IFC President. The President annually calls for nominations from sections and members of the forest sector for the CIF/IFC national awards, and the Executive Committee collectively review the nominations received and decide on the award recipients. The awards are presented at the CIF/IFC Annual General meeting.
Il est possible d'obtenir un large éventail d'alternatives forestières à partir des forêts naturelles jusqu'aux fermes forestières aménagées intensivement. Nous croyons qu'un regroupement planifié des utilisations forestières requises pour répondre aux besoins canadiens, devrait être issus d'un dialogue public informé. Nous membres devraient jouer un rôle constructif de facilitateur dans ce débat.

(Adopté lors de l'assemblée annuelle 1996 du CIF/IFC, révisions mineures en 1997)

\section{Structure organisationnelle du CIF/IFC}

En accord avec les règlements, les statuts et les règles de procédure du CIF/IFC, la structure organisationnelle consiste en un conseil d'administration, un comité exécutif, un directeur exécutif (directrice exécutive), l'équipe du Forestry Chronicle, les sections, le conseil et les comités nationaux ainsi que les groupes de travail.

Le conseil d'administration comprend un représentant de chaque section, ainsi que les membres du comité exécutif. Le conseil est responsable de la gestion des affaires de l'Institut. Les membres et le conseil des sections désignent un représentant pour siéger sur le conseil d'administration national du CIF/IFC.

Le comité exécutif guide, dirige et assiste par ailleurs le directeur exécutif (la directrice exécutive) dans la gestion des affaires de l'Institut. Le comité est constitué par:

Le président - le directeur général de l'Institut

Le président sortant

Le premier vice-président

Le second vice-président

Le comité exécutif est élu par les membres. Des nominations pour le poste de second et de premier vice-président sont requises chaque année, et au besoin un vote par scrutin peut être tenu. Le premier vice-président assume automatiquement le poste de président, et le président assume automatiquement le rôle de président sortant.

Le directeur exécutif, un salarié occupant un poste à temps plein au sein de l'Institut, est responsable des opérations quotidiennes de l'Institut et de la gestion du bureau national, situé à Ottawa.

Le Forestry Chronicle est géré par une équipe chargée de l'édition et composée d'un éditeur, d'un éditeur scientifique, d'un directeur de la production et du directeur exécutif. Les annonces publicitaires du Chronicle sont gérées à l'interne par le personnel du CIF/IFC.

Les sections peuvent être formées suite au dépôt d'une demande réalisée par cinquante membres votants ou par une résolution acheminée au conseil d'administration. Il y a actuellement 23 sections. Les sections forment la "première ligne" des opérations de l'organisation, et sont dirigées par des bénévoles dans la plupart des cas et représentent un lien direct avec les membres.

\section{Les comités et les conseils nationaux}

Le comité des finances

Il est désigné par le comité exécutif. Le comité supervise l'état des finances de l'Institut et assiste le directeur exécutif dans la préparation du budget annuel qui doit être approuvé lors de l'assemblée générale annuelle.

\section{Le comité des prix}

Il comprend le comité exécutif, et est présidé par le président du CIF/IFC. Le président sollicite des candidatures auprès des sections et des membres du secteur forestier pour la remise des prix de l'Institut, et le comité exécutif révise col- 


\section{Nominating Committee}

Annually the President appoints the Past President to be the chair of Nominating Committee. The chair calls for nominations for the Executive committee $1^{\text {st }}$ and $2^{\text {nd }}$ Vice-President positions. The Nominating chair announces to the membership if a ballot vote is required for the nominations.

\section{By-Laws Committee}

Appointed by the Executive Committee from time to time to review the CIF/IFC by-laws.

\section{Resolutions Committee}

The chair is appointed annually by the President to receive, review and deliver the resolutions to the members at the CIF/IFC annual meeting.

\section{Strategic Planning Task Force}

A task force, chaired by the $1^{\text {st }}$ Vice -President, struck to develop and oversee CIF/IFC's strategic plan.

\section{Standing Committee on Restructuring}

A committee, chaired by the $2^{\text {nd }}$ Vice-President, struck to review CIF/IFC's structure and to make recommendations for change.

\section{History Committee}

A committee that reviews the Institute's history, prepares historical documents for publication, oversees the proper archiving of CIF/IFC material and undertakes special projects.

\section{Membership Committee}

A committee, chaired by the $1^{\text {st }}$ Vice-President, that oversees the membership recruiting of the Institute.

\section{Host Annual Meeting Planning Committee (HAMPCO)}

The local section steering committee formed to prepare and deliver the CIF/IFC annual general meeting and conference.

\section{Forestry Awareness in Canada Trust (FACT)}

A foundation established to receive donations for the promotion of Forestry Awareness in Canada. Promotional activities include field trips for schools, MLAs, MPs and media, demonstration forests, publications (i.e. articles, books, brochures). FACT is administered by a President and Trustees appointed by the CIF/IFC Board of Directors.

\section{Forest Science and Technology Board (Working Groups)}

Established in 1983, the Forest Science and Technology Board (FSTB) is comprised of the working group chairs. Working Groups consist of members interested in a particular field of forestry and are organized generally for the purpose of disseminating information through the development of position papers, and/or holding technical workshops. There are currently 12 Working Groups as follows:
1. Forest Ecology
6. Forest Harvesting
2. Forest Economics \& Policy
3. Forest Education
7. Forest Hydrology
4. Forest Management
5. Forest Pest Management
8. Forest Measurement

lectivement les candidatures reçues et annonce les nominations pour les prix. Les prix sont remis lors de l'assemblée générale annuelle du CIF/IFC.

\section{Le comité de nomination}

Le président désigne chaque année le président sortant comme étant le président du comité de nomination. Le président du comité sollicite des candidatures pour les postes de premier et second vice-président du comité exécutif. Le président du comité de nomination indique aux membres si un vote par scrutin est nécessaire pour les nominations.

\section{Le comité des règlements}

Le comité est désigné par le comité exécutif lorsque requis pour effectuer une révision des règlements.

\section{Le comité des résolutions}

Le président du comité est nommé chaque année par le président de l'Institut et a la responsabilité de recevoir, de réviser et de présenter les résolutions aux membres lors de l'assemblée annuelle du CIF/IFC.

\section{Le groupe de travail sur le plan stratégique}

Ce groupe de travail, présidé par le premier vice-président, est mis en place pour élaborer et superviser le plan stratégique de l'Institut.

\section{Le comité permanent sur la restructuration}

Ce comité, présidé par le second vice-président, est mis en place pour réviser la structure de l'Institut et pour effectuer des recommandations de changement.

\section{Le comité sur l'histoire de l'Institut}

Un comité chargé de réviser l'histoire de l'Institut, prépare les documents historiques pour des fins de publication, supervise l'archivage adéquat du matériel de l'Institut et entreprend des projets spéciaux.

\section{Le comité sur le recrutement de membres}

Un comité, présidé par le premier vice-président, supervise le recrutement des membres de l'Institut.

\section{Le comité organisateur de l'assemblée annuelle (HAMPCO)}

Un comité de direction au niveau de section hôte de l'assemblée annuelle est mis en place pour préparer et tenir l'assemblée générale annuelle et la conférence de l'Institut.

Le Fonds de sensibilisation à la foresterie du Canada (FACT)

Une fondation a été mise en place pour recueillir les dons effectués pour la promotion de la sensibilisation à la foresterie au Canada. Les activités promotionnelles comprennent les excursions sur le terrain pour les écoles, pour les députés provinciaux, pour les députés fédéraux et les médias, les forêts de démonstration, des publications (p.ex. des articles, des livres, des brochures). Le FCAT est géré par le président et les mandataires désignés par le conseil d'administration de l'Institut.

\section{Le comité des sciences et technologies forestières (Groupes de travail)}

Créé en 1983, le comité des sciences et technologies forestières(CSTF) est formé par les présidents des groupes de travail. Les groupes de travail sont formés de membres intéressés par un domaine particulier de la foresterie et sont organisés généralement dans le but de disséminer de l'information par l'entremise d'énoncés ou également par la tenue d'ateliers techniques. Il y a actuellement 12 groupes de travail dans les domaines suivants:
1. L'écologie forestière
2. L'économie et les politiques forestières
4. L'aménagement forestier
3. La formation en foresterie
5. Le contrôle des ravageurs forestiers
6. L'exploitation forestière 


\section{Silviculture \& Tree Improvement}

11. Wildlife and Fish Habitat

12. Non-Industrial Forestry

\section{Membership}

Active Members.

Active Member status is granted to persons who, through post-secondary training and education, have earned a certificate, a diploma or a degree in forestry or forestry-related disciplines as may be identified from time to time by the Board of Examiners.

Other qualification can be granted to persons who hold responsible forestry or forestry-related positions, or who have been engaged in forestry or forestry-related practice for five years, or who, having expressed interest in forestry, are considered to have the potential to advance sound forestry practices.

\section{Student Members}

Existing Members in full-time study. Graduate or undergraduate students in full- time study - leading to qualification for Active membership.

\section{Retired Members}

Members who have been members of the Institute for 15 or more years and are retired can be granted retired membership.

\section{Corporate Sustaining Members}

Available for organizations involved in or providing a service to Canadian forestry or to the Institute.

\section{Roles and Activities}

The roles and activities of the CIF/IFC are guided by its Mission Statement, Objects and Values and Beliefs. Nationally the CIF/IFC has representation at International and National forums such as the World Commission on Forests and Sustainable Development, Canadian Criteria and Indicators, Canadian Standards Association. The CIF/IFC Working Groups develop position papers and provide technical sessions for members and the public. CIF/IFC also serves as the secretariat to the Canadian Federation of Professional Foresters Association and the Canadian Forest Pest Management Caucus. CIF/IFC organizes/co-hosts conferences that promote sustainable forest management (e.g. Silviculture Conference, Forest Educator's conference, Sustainable Forests: From Theory to Practices). CIF/IFC is a member of the National Forest Strategy Coalition and serves on several committees within the Coalition.

CIF/IFC Sections are located regionally and provide technical sessions/field tours for members and non-members, talk with local media, MPs, MLAs, and municipal government about forestry practices and policies. Section representatives meet with university and college students and provide the networking opportunities that future forest workers need. Over the years, several sections have been instrumental in establishing Registered Professional Foresters Associations in their province. In Newfoundland, the CIF/IFC section administers the RPF program. In Saskatchewan and Nova Scotia, the $\mathrm{CIF} / \mathrm{IFC}$ sections are pursuing RPF program, and the Manitoba CIF/IFC section is pursuing a RPF and Technician program.

\section{The Forestry Chronicle}

The Forestry Chronicle is the official journal of the Canadian Institute of Forestry/Institut forestier du Canada
7. L'hydrologie forestière

8. La dendrométrie

9. La foresterie internationale

11. Les habitats fauniques et halieutiques

12. La foresterie non industrielle

10.La sylviculture et l'amélioration génétique

\section{Les membres}

Les membres actifs

Le statut de membre actif est accordé aux personnes qui, suite à une formation et une éducation post-secondaire, ont reçu un certificat, un diplôme ou un baccalauréat en foresterie ou dans une discipline reliée à la foresterie comme peut le désigner au besoin le bureau des examinateurs.

D'autres qualifications peuvent être accordées aux personnes qui détiennent un poste de haut niveau en foresterie ou dans un domaine relié à la foresterie, ou qui ont travaillé en foresterie ou dans un domaine connexe pendant cinq ans, ou qui, ayant démontré un intérêt pour la foresterie, sont considérées comme ayant le potentiel de faire progresser de saines pratiques forestières.

\section{Les membres étudiants}

Membres actuels aux études à temps plein. Étudiants gradués et pré-gradués aux études à temps plein et qui se qualifieraient comme membres actifs.

\section{Les membres retraités}

Les personnes qui ont été membres de l'Institut pendant 15 ans ou plus et qui sont à la retraite, peuvent recevoir le statut de membre retraité.

\section{Les membres corporatifs}

Catégorie disponible pour les organisations impliquées en foresterie ou qui procurent un service en foresterie au Canada ou à l'Institut.

\section{Rôles et activités}

Le rôle et les activités de l'Institut sont définis par l'énoncé de sa mission, de ses objectifs et de ses valeurs et croyances. À l'échelle nationale, l'Institut détient un siège sur les forums internationaux et nationaux comme la Commission mondiale sur les forêts et le développement durable, les Critères et Indicateurs canadiens, l'Association canadienne de normalisation. Les groupes de travail de l'Institut élaborent des mémoires et présentent des sessions techniques pour les membres et le public. L'Institut agit également en tant que secrétariat de la Fédération canadienne des associations de forestiers professionnels ainsi que pour le Comité canadien de contrôle des ravageurs forestiers. L'Institut organise ou est le co-hôte de conférences qui font la promotion de l'aménagement forestier durable (par exemple la Conférence sur la sylviculture, la conférence pour les enseignants en foresterie, Les Forêts durables: De la théorie à la pratique). L'Institut est un membre de la Coalition nationale sur la stratégie forestière et participe à plusieurs comités de la Coalition.

Les sections de l'Institut sont constituées régionalement et procurent une aide technique ou élaborent des excursions techniques pour les membres et non membres, discutent avec les médias locaux, les députés fédéraux, les députés provinciaux et les gouvernements municipaux des pratiques et de politiques forestières. Les représentants des section rencontrent les étudiants universitaires et collégiaux et établissent des possibilités de réseautage nécessaires aux futurs travailleurs forestiers. Au cours des ans, plusieurs sections ont joué un rôle déterminant dans la création d'une association de forestiers professionnels inscrits dans leur province. À Terre-Neuve, la section locale de l'Institut gère le programme des forestiers professionnels inscrits. En Saskatchewan et en Nouvelle-Écosse, les sections de l'Institut cherchent à établir un programme de forestiers professionnels inscrits, et au Manitoba, la section de 
(CIF/IFC). The Forestry Chronicle was first published in 1925 and remains the foremost Canadian forestry publication worldwide.

\section{Annual Meetings}

Annual Meetings move around the country and are held in the late summer/early fall of each year. A Host Annual Meeting Planning Committee (HAMPCO) coordinates the meeting. A two to three day conference with a one-day field tour accompanies the Annual General Meeting of members.

\section{Awards and Rings}

CIF/IFC awards program acknowledges the outstanding accomplishment of Canadian individuals. The Canadian Forestry Achievement, Canadian Scientific Achievement, International Forestry Achievement, Canadian Forestry Group Achievement and the James M. Kitz awards are awarded annually to individuals who have demonstrated outstanding performance in forestry. Honourary and Fellow members are also awarded by the Institute from time to time. One student at each University and Technical forestry school receives a Gold Medal from the Institute and graduating students from an undergraduate forestry degree program receive a silver forestry ring. Several other prizes exist within the sections as well. Each Section has the opportunity to recognize a member by presenting a Tree of Life Award. CIF/IFC also recognizes members who have been members of the Institute for 50 years as a Golden Year member.

\section{Continuing Forestry Education Program}

The Continuing Forestry Education Program (CFE) was launched in June 1995. The program has been adopted by the Registered Professional Foresters Associations and Technician/Technologist Associations in several provinces. This program provides a member and non-member with the means to track Continuing Education hours and be recognized through a certificate after 150 hours have been completed over a three-year period.

\section{Accreditation}

CIF/IFC appoints a representative to the Canadian Forestry Accreditation Board. This Board accredits forestry undergraduate programs at Canadian Universities.

\section{CIF/IFC Strategic Elements to the 1998-2003 Strategic Plan}

\section{To Promote Excellence in Members}

To advance members in their knowledge in forestry.

To cultivate an esprit de corps among members.

To publish a professional and scientific forestry journal.

a) Involve membership and provide leadership in an International Program.

b) Involve the membership in the Continuing Forestry Education Program.

c) Promote and support Working Groups and activities.

d) Develop and update an effective and informative internet service.

e) Ensure The Forestry Chronicle meets the needs of the membership.

f) Hold an Annual General Meeting for members and a conference.
l'Institut cherche à établir un programme de forestiers professionnels inscrits et un programme pour les techniciens.

\section{Le Forestry Chronicle}

Le Forestry Chronicle est la revue officielle du Canadian Institute of Forestry/Institut forestier du Canada (CIF/IFC). Le Forestry Chronicle a été publié une première fois en 1925 et demeure l'une d'une publication de l'avant-scène à l'échelle mondiale.

\section{Les assemblées annuelles}

Les assemblées annuelles se déplacent un peu partout au pays et ont lieu chaque année à la fin de l'été ou au début de l'automne. Un comité de direction de l'assemblée annuelle (HAM$\mathrm{PCO}$ ) voit à l'organisation de l'assemblée. Une conférence de deux à trois jours comprenant une excursion technique a lieu conjointement avec l'assemblée générale annuelle des membres.

\section{Les prix et les joncs}

Le programme de prix de l'Institut souligne les réalisations remarquables d'individus ici au Canada. Le prix pour une réalisation remarquable en foresterie au Canada, le prix pour une réalisation remarquable en recherche forestière au Canada, le prix pour une réalisation remarquable en foresterie internationale, le prix pour une réalisation remarquable d'un groupe en foresterie au Canada et le prix James M. Kitz, sont remis chaque année aux personnes qui ont fait preuve d'une performance hors de l'ordinaire en foresterie. Des membres honoraires et des membres émérites sont également nommés à l'occasion par l'Institut. Un étudiant de chaque université et de chaque collège technique de foresterie se mérite la Médaille d'or de l'Institut et les étudiants qui graduent d'un programme de baccalauréat en foresterie reçoivent un jonc d'argent de forestier. Il existe également plusieurs autres prix remis par les sections. Chaque section a la possibilité de reconnaître un membre en lui remettant le prix de l'Arbre de la vie. L'Institut reconnaît également les personnes qui sont membres de l'Institut depuis 50 ans en leur accordant une nomination au sein des membres jubilaires.

\section{Le programme de formation continue en foresterie}

Le programme de formation continue en foresterie (FCF) a été lancé en 1995. Le programme a été adopté par les associations de forestiers professionnels inscrits et par les associations de techniciens/technologistes de plusieurs provinces. Ce programme procure au membre et au non-membre un outil pour enregistrer les heures de formation continue auxquelles il participe et permet d'obtenir un certificat d'attestation après avoir complété 150 heures au cours d'une période de trois ans.

\section{Agrément}

L'Institut désigne un représentant au sein du Bureau canadien d'agrément en foresterie. Ce bureau remet un agrément aux programmes de baccalauréat en foresterie dispensés par les universités canadiennes.

\section{IX. Éléments stratégiques pour l'institut selon le plan stratégique de 1998-2003}

1. Promotion de l'excellence parmi les membres

Faire progresser les membres dans leur connaissance de la foresterie.

Cultiver un esprit de corps parmi les membres.

Publier une revue forestière professionnelle et scientifique.

a) Impliquer les membres et assumer le leadership d'un programme international.

b) Impliquer les membres dans le programme de formation continue en foresterie.

c) Promouvoir et appuyer les groupes de travail et leurs activités.

d) Élaborer et mettre à jour un service Internet efficace et informatif. 


\section{To Enhance Professionalism in Forestry}

To provide leadership in all aspects of forestry in Canada.

To recognize through a national awards program the outstanding contributions made to forestry by members and non-members. To recognize and welcome to the profession, graduates from Canadian university forestry schools through the presentation of forestry rings.

a) Participate in policy committees both provincially and nationally.

b) Develop a relationship with politicians/municipal leaders.

c) Promote the CIF/IFC Awards program nationally and internationally.

d) Participate in the National Forest Strategy Coalition.

e) Review the CIF/IFC silver ring program and the technician/technologist recognition program.

f) Develop rapid response capability.

\section{To Facilitate Public Awareness of Forestry}

To foster public understanding of forestry, and its importance to Canada

To cooperate with other organizations having similar objectives.

a) Develop without duplication or participate in one focussed public education program.

b) Promote through partnerships the best available information about Canadian forests, policies and practices.

c) Increase awareness about socio economic issues and traditional knowledge

\section{To Provide Quality of Service}

To increase communication

To retain and increase membership

a) Develop a communications plan to ensure effective communication among national executive, section executive and individual members.

b) Develop a membership recruitment and retention plan.

c) Explore the recommendations of the Restructuring Task Force.

\section{To Ensure Stability of the Institute}

To identify alternate resources of funding

To operate effectively and economically

a) Develop a Business plan that will outline how the organization should be and can be financially resourced.

b) Establish a strong foundation through FACT.

This plan was developed by the Strategic Plan Task Force in cooperation with the CIF/IFC Sections, Working Group chairs and the Executive Committee. The plan was approved by the Board of Directors at the October 1998 Board of Directors meeting in Ottawa, Ontario.

Strategic Plan Task Force members:

Evelynne Wrangler (Task Force Chair)

Bruce Ferguson

John Hall

Ralph Roberts

Jean-Louis Wallace

Roxanne Comeau (ex-officio member) e) S'assurer que le Forestry Chronicle réponde aux besoins des membres.

f) Tenir une assemblée générale des membres et une conférence annuelles.

\section{Accroitre le professionnalisme en foresterie}

Assumer un leadership dans tous les aspects de la foresterie au Canada.

Souligner par l'entremise d'un programme national de prix, les réalisations remarquables en foresterie des membres et des non-menbres.

Souligner et accueillir au sein de la profession, les gradués des écoles et facultés universitaires par la remise des joncs de forestiers.

a) Participer aux comités sur les politiques tant sur la scène provinciale que nationale.

b) Développer des relations avec les politiciens et les leaders municipaux.

c) Promouvoir le programme des prix de l'Institut sur la scène nationale et internationale.

d) Participer aux travaux de la Coalition nationale sur la stratégie forestière.

e) Réviser le programme de jonc de forestier de l'Insitut et le programme de reconnaissance des techniciens/technologistes.

f) Développer un système de réponse rapide.

\section{Faciliter la sensibilisation du public en matière de} foresterie

Favoriser la compréhension de la foresterie chez le public, ainsi que son importance au Canada.

Coopérer avec d'autres organisations ayant des objectifs semblables.

a) Élaborer sans duplication ou participer à un programme centré sur l'éducation du public.

b) Diffuser par l'entremise de partenariat la meilleure information disponible sur les forêts, les politiques et les pratiques forestières canadiennes.

c) Accroître la sensibilisation sur les enjeux socio-économiques et les connaissances traditionnelles.

\section{Procurer un service de qualité}

Accrôtre les communications.

Retenir les membres et augmenter le nombre de membres.

a) Élaborer un plan de communication qui permet d'établir une communication

Effective entre les membres de l'exécutif national, les membres des conseils de section et les membres individuels.

b) Élaborer un plan de recrutement et de rétention des membres.

c) Étudier les recommandations du groupe de travail sur la restructuration.

\section{Assurer la stabilité de l'Institut}

Identifier des ressources alternatives de financement.

Fonctionner de façon efficace et économique.

a) Élaborer un plan d'affaires qui soulignera comment l'organisation devrait et pourrait compter sur un nouveau mode de financement.

b) Établir un fonds stable par l'entremise du FACT.

Ce plan a été élaboré par le groupe de travail sur le plan stratégique en collaboration avec les sections de l'Institut, les présidents des groupes de travail et le comité exécutif. Le plan a été approuvé par le conseil d'administration lors de la réunion d'Ottawa (Ont.) tenue en octobre 1998.

Les membres du groupe de travail:

Evelynne Wrangler (présidente du groupe de travail)

Bruce Ferguson

John Hall

Ralph Roberts

Jean-Louis Wallace

Roxanne Comeau (membre ex-officio) 


\section{The Forestry Chronicle Annual Report, 1997-1998}

\section{Introduction}

Six issues of The Forestry Chronicle were published during the fiscal year, 1 July 1997 to 30 June 1998 . These were numbers 4-6 of Volume 73 and numbers 1-3 of Volume 74.

Summary commentary on the financial status of the Journal, its contents, special features, and changes follow.

\section{Financial Status}

During 1997-98, the revenues generated by The Forestry Chronicle totaled $\$ 132177$ (unaudited). The revenues for the previous year totaled $\$ 135030$. The $1997-98$ income was derived from advertising (38.2\%), page charges (23.8\%), subscriptions $(23.8 \%)$, and reprints $(14.2 \%)$.

Expenditures of $\$ 138,483$ (unaudited) (compared to $\$ 124630$ last year) was distributed as follows: printing (53.5\%), editing and production (17.2\%), advertising (11.0\%), and mailing, reprints and miscellaneous $(18.3 \%)$. The net loss to the Institute was $\$ 6309$ (unaudited) (compared to a gain of $\$ 10400$ in 1996). This loss is due largely to an increase in printing and a slight decrease in reprint and advertising revenue.

\section{Content}

The six issues contained 860 pages compared to 774 in 1996-97. The distribution of pages is recorded in the accompanying table. The percentage of distribution of pages was as follows:

Professional articles

$20 \%$

Scientific and technical papers $\quad 18 \%$

Special features

$13 \%$

Other topics

$49 \%$

e.g. News, Meetings, Editorials, President's Perspective, Letters, Advertisements, and Institute Affairs.

During the year, 96 manuscripts were reviewed: 44 were published, 10 were rejected, and 5 have been accepted and are waiting final editing, 6 have been returned to authors for revision, 1 is inactive, 12 are with reviewers and 18 have been approved and will be published in the July/August issue. This production would not have been possible without the exceptional and essential assistance of the Associate Editors. This collaboration is gratefully acknowledged.

\section{Special Features}

The following special features were published:

- CIF/IFC Annual Meeting Papers (1996)

- Sustainable Site Productivity in Canadian Forests

- Seed Tree Working Group

- The Great Ice Storm of 1998

- Aboriginal Forest Issues

\section{Changes to The Forestry Chronicle}

The main findings resulting from the survey questionnaire with CIF/IFC Sections follow:

- Changes in format have significantly improved the Chronicle and the balance of features is about right

- The level of interest in features is high in:

- National and International news

- Emphasis on articles of a professional/general nature

\begin{tabular}{lccccc}
\hline Contents of the Forestry & Chronicle, 1993-1994 to 1997-1998 \\
\hline & $1993-94$ & $1994-95$ & $1995-96$ & $1996-97$ & $1997-98$ \\
\hline $\begin{array}{l}\text { Number of Professional } \\
\text { Papers }\end{array}$ & 18 & 13 & 41 & 25 & 26 \\
$\begin{array}{l}\text { Pages of Professional } \\
\text { Papers }\end{array}$ & 72 & 73 & 231 & 149 & 176 \\
$\begin{array}{l}\text { Number of Scientific } \\
\text { Papers }\end{array}$ & 24 & 32 & 31 & 13 & 19 \\
$\begin{array}{l}\text { Pages of Scientific } \\
\text { Papers }\end{array}$ & 167 & 215 & 169 & 79 & 155 \\
Pages of Special Features & 177 & 151 & 36 & 151 & 108 \\
Pages of Other Material & 330 & 430 & 305 & 357 & 421 \\
Total Pages & 764 & 870 & 741 & 774 & 860 \\
\hline
\end{tabular}

- The long range listings of conferences to facilitate travel planning

- News from sections, professional associations, educational institutions, and global village communications

Regarding further improvements in content:

- Continue the emphasis on professional articles

- Increase the news from sections, professional associations, and people profiles, and interviews

- Maintain and enhance national and international news topics

- Continue to enhance the use of photographs and illustrations

- Include papers reviewing Canadian forest history

In addition, advance planning of themes for each of the issues during the next calendar year has begun and these themes will be publicized in both the CIF/IFC website and in the journal itself.

Of 20 subject areas requested for coverage in articles, the following seven were particularly emphasized:

- Forest history

- Social forestry

- Non-timber values

- Public relations and education

- Criteria and indicators/certification and sustainability

- Urban forestry/environmental issues

- Forest renewal

\section{Acknowledgments}

A quality journal cannot be produced without the assistance of many volunteers including associate editors, book reviewers, and authors and reviewers, both national and international, as well as the many contributors to Editorials, Special Features, and "Other topics." Appreciation is expressed to these individuals for their exceptional collaboration.

We also thank CIF/IFC staff, Cherry Maxwell and Sue Easterman, for their capable support on matters related to the Journal.

Roxanne Comeau, Tim Fenton, Brian D. Haddon, and Vidar J. Nordin 


\section{Report of the Finance Committee for Fiscal Year 1997-1998}

\section{Highlights}

Members of the Committee for 1997-98 were Bill Fullerton, Don Lockhart, Jean-Louis Wallace (Chairperson) and Roxanne Comeau. One meeting was held in 1997-98.

The enclosed table presents the year-end position relative to the 1997-98 budget. A draft budget for 1998-99 is also enclosed. The results for the year represent an approximate $\$ 55000$ difference from the previous year 1996-97, when the Institute's balance was in excess of $\$ 48000$. In 1997-98, the balance represents a loss of more than $\$ 6000$. The Committee considers that the financial outlook for the CIF/IFC is still positive.

The CIF/IFC still maintains the cost control policies that were put into place in the last few years. Revenues in 1997-97 increased marginally over what we had budgeted while our overall expenditures increased slightly. As a result of those increas$\mathrm{es}$, the CIF/IFC has identified areas that will require stringent cost control measures. Those areas are outlined in our report.

The Committee has expressed general concerns with the increased costs of AGMs. The Committee suggests that a task force be appointed to examine new options for AGMs.

Finally, while the balance sheet is not as impressive as the last few years, the Committee does not feel it is necessary to increase membership dues.

Details of the CIF/IFC Finance Committee report are outlined below.

\section{Revenues in 1997-98}

Total revenues were within budget.

Membership Fees: membership fees continue to remain the primary source of revenue for the Institute. Revenues from this line item increased by four per cent. While it is still too early to measure the impact of the recommendations of the membership task force implemented last year, the current increase in revenue can be attributed to an increase in membership from British Columbia and Newfoundland. These provincial Professional Forester's Associations have instituted a joint membership package with the CIF/IFC. As a result, the increase in membership from those provinces is most likely a one-time event.

Sustaining Members: Commonly referred to as our corporate membership category, this line item has remained relatively unchanged. Future increases in revenue for this line item are seen to be limited, as the forest industry appears to be going through another period of consolidation. As a result, the Institute may wish to consider seeking potential sustaining members from other sectors that benefit or provide services to the forestry community.

Interest: Interest represents the money earned from our investments with financial institutions. Since our revenue reserves are placed in secure deposits and interest rates are forecasted to remain low for the foreseeable future, we do not expect this line item to change significantly over the next few years.

Life Insurance: Monies earned from this line item are from members of the Institute who have decided to adhere to the life insurance policy that was offered at the time. Revenues for the current year are lower than expected and this can be attributed to the billing period. Revenues are anticipated to double next year.
While not life insurance specialists, the Committee proposes that the Institute evaluate the merit of offering an alternative life insurance package that would generate an improved source of revenue for the Institute and possible benefits to policyholders. We would suggest that members who could offer assistance or advice on this subject submit their comments directly to the Institute.

Special Projects (Schedule A): The potential for revenues from this line item has not been very successful in the past year. The revenue deficit can be associated to two factors: (a) the cost associated in scheduling conference calls for the various CIF task forces; (b) the China project came to a term this year and resulted in an additional $\$ 2000$ in unexpected expenditures for the Institute. There is a possibility that this project may be renewed or that the Institute could obtain funding through CIDA for similar projects. We are unable to assess the success or failure of the project at this time, as this would require it be evaluated in its entirety (from start to finish).

In the future, prior to undertaking such projects the Committee strongly suggests that the Institute ensure that the projects are financially self-sustaining.

\section{Expenditures in 1997-98}

While not final at the time of writing the financial report, the Committee anticipates that overall expenditures will have increased by nearly $\$ 50000$ compared to the previous year. This places the Institute in a deficit situation of more than $\$ 6000$. This deficit, the first in three years, represents less than five per cent of the Institute's operating budget, which is considered to be reasonable. This, according to standard accounting practices, is considered to be reasonable.

The increase in expenditures can be attributed to the following line items.

Salaries: While salaries increased in the last year, the increase was insignificant. A modest two per cent increase in salaries has been budgeted for next year.

Travel Executive Committee: Travel by the Executive Committee increased substantially in the past year. Part of the reason for the increase can be attributed to the fact that we have representation of the executive from various sections of the CIF. Secondly, it has been difficult for a number of executive members to have their employer cover the costs to attend CIFsponsored events. Hence, given the importance of the Executive meeting on a regular basis, these costs were deemed by the Finance Committee as falling within the norm of doing business.

Travel Executive Director: The increase in travel expenditures by the Executive Director reflects the policies established by the Executive Committee to have the Executive Director visit the various $\mathrm{CIF}$ sections more frequently and also to attend regional fora associated with the National Forest Congress. Future expenditures under this line item will continue to reflect the directives and policies established by the Executive.

Rent and Hospitality: The Finance Committee has budgeted for similar operating expenditures similar to 1997-98 expenditures for these line items. Rent is expected to remain unchanged. 
Translation: The substantial savings in translation reflect the CIF's ability to have members translate documents when necessary or have the documents initially written in the language requested. The Finance Committee does not expect to see this line item increase in 1998-1999.

Office Expenses: Once again, the office was able to keep this line item under check. While expenditures were reduced by eleven per cent, the Finance Committee felt that it would be prudent to budget for similar expenditures as those provided for in 1997-1998.

On-line Services: On-line services represented a substantial increase in expenditures. The increase can be associated with the development of our web page and the decision to enlist John Roper's web page services. While still in the initial stages of development, the CIF anticipates costs to decrease significantly in the next few years, as we become more knowledgeable in maintaining the web page.

Office Equipment: Office equipment reflects a new line item that the Finance Committee suggested the CIF incorporate in its expenditures. This line item represents costs associated with software upgrades and purchases to ensure the daily operations of the office for CIF members. Costs are expected to fluctuate pending the services provided to members.

Mail/Courier: The Finance Committee welcomes the decrease in expenditures for this line item. The Committee has budgeted identical expenditures as those provided for in 1997-1998. Members, however, should be cautioned that this line item can fluctuate significantly from year to year.

Accreditation: The decrease in expenditures was anticipated since the CIF accredited the same number of schools as the previous year. Three schools are slated to be accredited in the next year.

Audit: This item represents the CIF's annual expenditure to have its operating ledgers verified by a chartered accountant.

Telephone/Fax: Expenditures are within budget. The Finance Committee expects expenditures to be similar for the 1998-1999 fiscal year.

Print: Printing expenditures have increased over 1996-97 figures. This increase can be attributed to the larger quantity of information mailed to members and the increase in requests.

Bank: This item represents bank service charges assessed to the Institute for its various contracted financial services. The Finance Committee expects similar bank charges for the next fiscal year.

Forestry Chronicle (Schedule B): The increase in expenditures can be attributed to a number of factors. For instance, professional articles have increased and provided diversity to our readership though often they do not obtain full page charges. Other increases appear to be reflective of the cost of doing business and promoting our flagship, The Forestry Chronicle.

Many thanks to the Editors for their ability to seek profits from the issue on Aboriginal Forestry. This issue alone was responsible for the increase in reprint revenues. This issue could perhaps serve as a template for future issues of The Forestry Chronicle. In addition, the Editors of The Forestry Chronicle may have found a market niche in printing forestry-related articles of interest to other forestry-related groups that do not have a journal for their members.
AGM (Schedule C): In reviewing the expenditures of the AGM, the Finance Committee has expressed general concerns with the increased costs of hosting these meetings. In the last year, the Committee budgeted for a cost of $\$ 17000$. The final figure exceeded our estimate by more than $\$ 7000$.

The greatest increase in expenditures was associated with Director travel. The Finance Committee recognizes that the location of the meeting will play an important role in determining the expenditures. The Committee also has concerns that the 1998 HAMPCO has already borrowed more than $\$ 16000$ from CIF National Office. Past practice has been for National Office to advance no more than $\$ 5000$ to HAMPCO.

Moreover, with the consolidation and integration of the forest industry it is becoming increasingly difficult for sections to obtain funding from industry and government for our yearly AGM's.

While it is too early to determine the financial outcome of the ' 98 AGM, the Finance Committee has expressed concerns about the Institute's ability to host future meetings without them having a serious impact on the Institute's overall balance sheet.

It is the Committee's understanding that the purpose of the AGM is to address CIF business issues. With less than ten per cent of the members attending the actual CIF business meetings in the last few years, the Committee questions whether it is appropriate to have Annual General Meetings following the current format.

The Committee recognizes the importance of having these meetings; however, it is also important that, from time to time, the Institute review its policies to ensure that future meetings not only meet members objectives but they also remain viable.

As such, the Committee suggests that the Executive Committee consider appointing a task force within the next year with a mandate to: (a) determine the viability of shortening the meeting to two days (pressures from work and other issues makes it difficult for delegates to justify attending four days of meetings); (b) determine an alternate medium for conducting business meetings that would result in a greater representation of member participation; (c) determine the viability of having AGMs, in the current format, every second year; (d) determine whether a permanent HAMPCO and National Sponsor be established for our meetings; and (e) determine whether CIF sections should have financial commitments secured prior to expressing an interest in hosting the AGMs.

These items should simply be taken as suggestions that could form the basis of initial discussions for the task force.

We have raised this issue because both The Forestry Chronicle and the AGM appear to be the two line items that have a tendency to fluctuate from one year to the next.

Notwithstanding the fact that a five per cent loss, or $\$ 11000$ of the CIF's operating budget, falls within the norm of standard accounting practices, this does not preclude the fact that we have to look at the long term viability of the Institute. As a result, this may require changes to how we do business, if we decide to offer the same or better services to existing and future members.

Finally, Miscellaneous expenditures represent expenditures associated with medals/awards and rings. The overall increase in this line item was twenty-five per cent. In the future, the Institute could see a substantial increase in expenditures for rings should the CIF decide to issue rings to technicians. 
If the Institute decided to offer rings to technicians, expenditures will have to be revised to reflect such a decision.

Meanwhile, the Committee has budgeted an increase of $\$ 100$ over the previous year's budget.

\section{Budget for 1998-1999}

The Finance Committee has prepared a draft budget for 1998-1999 (please see the enclosed table).

\section{Conclusion}

After a careful review of the CIF operating budget on behalf of the CIF members, the Finance Committee anticipates that the Institute will lose approximately $\$ 11000$ in fiscal year 1998-1999. However, the final outcome will largely depend, as it does every year, on the success or failure of both The Forestry Chronicle and the AGM.

With these figures in hand, the Committee feels comfortable to once again forgo any increase in annual membership dues.

On behalf of the Institute, I extend my thanks to the members of the Finance Committee for their work in 1997-98.

Respectively submitted by: Jean-Louis Wallace Chairperson

\section{Auditor's Report}

To the Members of the Canadian Institute of Forestry

\section{- Institut Forestier du Canada}

We have audited the balance sheet of the Canadian Institute of Forestry - Institut Forestier du Canada as at June 30, 1998 and the statement of operations and surplus for the year then ended. These financial statements are the responsibility of the Institute's management. Our responsibility is to express an opinion on these financial statements based on our audit.

We conducted our audit in accordance with generally accepted auditing standards. Those standards require that we plan and perform an audit to obtain reasonable assurance whether the financial statements are free of material misstatement. An audit includes examining, on a test basis, evidence supporting the amounts and disclosures in the financial statements. An audit also includes assessing the accounting principles used and significant estimates made by management, as well as evaluating the overall financial statement presentation.

In our opinion, these financial statements present fairly in all material respects, the financial position of the Institute as at June 30, 1998 and the results of its operations for the year then ended in accordance with generally accepted accounting principles. Chartered Accountants

Canadian Institute of Forestry - Institut Forestier du Canada Balance Sheet - June 30, 1998

Assets

Current Assets

Cash

Short-term investments

Accounts receivable

Prepaid expense

Capital Assets

Office furniture and equipment

$\underline{\underline{\$ 203,846}} \quad \underline{\underline{\$ 214,958}}$

Current Liabilities

Liabilities and Equity

Accounts payable and accrued liabilities

Dues received in advance

Deferred revenue

\begin{tabular}{|c|c|}
\hline$\$ 12,449$ & $\$ 2,804$ \\
\hline 105,542 & 103,793 \\
\hline 7,503 & 23,412 \\
\hline 125,494 & 130,009 \\
\hline 78,352 & 84,949 \\
\hline$\$ 203,846$ & $\$ 214,958$ \\
\hline
\end{tabular}

Surplus

\begin{tabular}{|c|c|c|}
\hline \multicolumn{3}{|c|}{$\begin{array}{c}\text { Canadian Institute of Forestry - Institut forestier du Canada } \\
\text { Statement of Operations and Surplus } \\
\text { for the Year Ended June 30,1998 }\end{array}$} \\
\hline & 1998 & 1997 \\
\hline \multicolumn{3}{|l|}{ Revenue } \\
\hline Members' dues & $\$ 197,542$ & $\$ 197,146$ \\
\hline Sustaining members' dues & 20,530 & 21,225 \\
\hline Interest & 2,973 & 4,454 \\
\hline Life insurance commissions & 45 & 1,003 \\
\hline \multirow[t]{2}{*}{ Special projects (Schedule A) } & $(5,724)$ & $(2,093)$ \\
\hline & 215,366 & 221,735 \\
\hline \multicolumn{3}{|l|}{ Expenditures } \\
\hline Salaries & 97,078 & 92,207 \\
\hline Travel - Executive Committee & 2,288 & 933 \\
\hline Travel - Executive Director & 10,432 & 10,377 \\
\hline Rent & 15,051 & 15,167 \\
\hline Hospitality & 2,061 & 264 \\
\hline Translation & 479 & 1,513 \\
\hline Office & 13,834 & 15,448 \\
\hline E-mail/Web page & 6,403 & 3,650 \\
\hline Computer & 2,798 & - \\
\hline Mail/Courier & 8,307 & 9,885 \\
\hline Accreditation & 7,645 & 9,376 \\
\hline Audit & 5,116 & 4,877 \\
\hline Telephone/Fax & 6,290 & 8,052 \\
\hline Printing & 6,177 & 5,366 \\
\hline Bank charges & 568 & 506 \\
\hline Bad debt & 822 & - \\
\hline Forestry Chronicle (Schedule B) & 6,309 & $(10,400)$ \\
\hline Annual General Meetings (Schedule C) & 24,189 & (299) \\
\hline \multirow[t]{2}{*}{ Miscellaneous (Schedule D) } & 6,116 & 6,701 \\
\hline & 221,963 & 173,623 \\
\hline $\begin{array}{l}\text { Excess of (total expenditure over total } \\
\text { revenue) total revenue over total } \\
\text { expenditures for the year }\end{array}$ & $(6,597)$ & 48,112 \\
\hline Surplus - beginning of year & 84,949 & 36,837 \\
\hline Surplus - end of year & $\$ 78,352$ & $\$ 84,949$ \\
\hline
\end{tabular}




\begin{tabular}{|c|c|c|}
\hline \multicolumn{3}{|c|}{$\begin{array}{c}\text { Canadian Institute of Forestry - Institut Forestier du Canada } \\
\text { Schedule A } \\
\text { Statement of Operations - Special Projects } \\
\text { for the year ended June 30, 1998 }\end{array}$} \\
\hline & 1998 & 1997 \\
\hline \multicolumn{3}{|l|}{ Revenues } \\
\hline China-CIDA & $\$ 14,470$ & $\$ 42,899$ \\
\hline IWG - CIDA & 23,000 & - \\
\hline CFPFA & 120 & 1,844 \\
\hline OPFA/CIF Conference & - & 13,027 \\
\hline Canadian Criteria and Indicators & - & 2,000 \\
\hline Forest Pest Management Caucus & 1,109 & 1,663 \\
\hline \multirow[t]{2}{*}{ Miscellaneous } & 330 & - \\
\hline & $\$ 39,029$ & $\$ 61,433$ \\
\hline \multicolumn{3}{|l|}{ Expenditures } \\
\hline China-CIDA & $\$ 16,579$ & $\$ 42,899$ \\
\hline IWG - CIDA & 23,000 & - \\
\hline CFPFA & 353 & 2,495 \\
\hline OPFA/CIF Conference & - & 13,028 \\
\hline Canadian Criteria and Indicators & - & 664 \\
\hline Forest Pest Management Caucus & 1,109 & 1,662 \\
\hline \multirow[t]{2}{*}{ Task Force Projects } & 3,712 & 2,778 \\
\hline & $\$ 44,753$ & $\$ 63,526$ \\
\hline \multicolumn{3}{|l|}{ (Net cost) surplus of operating } \\
\hline Special Projects & $\$(5,724)$ & $\$(2,093)$ \\
\hline
\end{tabular}

Notes to the Financial Statements, June 30, 1998

\section{Significant accounting policy}

\section{a) Investments}

Short-term investments are recorded at cost, which approximates market value.

\section{b) Capital assets}

Purchases of office furniture and equipment are charged directly to expenditures. A nominal value of $\$ 1$ is carried on the balance sheet in recognition of the existence of such assets.

\section{Lease commitment}

The Institute leases office space at the following annual rates (excluding operating costs and municipal taxes):

$$
\begin{array}{ll}
1998 & \$ 8,304 \\
1999 & \$ 8,304
\end{array}
$$

\section{Other financial information}

The Institute, incorporated Federally as a corporation without share capital, qualifies as a non-profit organization for an exemption from income tax under Federal and Ontario legislation.
Canadian Institute of Forestry - Institut forestier du Canada Schedule B

Statement of Operations - Forestry Chronicle

\begin{tabular}{|c|c|c|}
\hline & 1998 & 1997 \\
\hline \multicolumn{3}{|l|}{ Revenue } \\
\hline Advertising & $\$ 50,489$ & $\$ 53,001$ \\
\hline Page charges & 31,555 & 32,010 \\
\hline Reprints/Colour production & 18,671 & 16,774 \\
\hline \multirow[t]{2}{*}{ Subscriptions } & 31,462 & 33,245 \\
\hline & $\$ 132,177$ & $\$ 135,030$ \\
\hline \multicolumn{3}{|l|}{ Expenditures } \\
\hline Editors & $\$ 15,250$ & $\$ 15,110$ \\
\hline Production & 8,540 & 7,420 \\
\hline Printing & 74,026 & 63,860 \\
\hline Mailing & 15,846 . & 15,185 \\
\hline Reprints & 1,728 & 2,067 \\
\hline Miscellaneous & 7,824 & 7,570 \\
\hline \multirow[t]{2}{*}{ Advertising } & 15,272 & 13,418 \\
\hline & $\$ 138,486$ & $\$ 124,630$ \\
\hline \multicolumn{3}{|l|}{ (Net cost) Net surplus of operating } \\
\hline Forestry Chronicle & $\$(6,309)$ & $\$ 10,400$ \\
\hline
\end{tabular}
for the year ended June 30, 1998

\begin{tabular}{|c|c|c|c|}
\hline \multicolumn{4}{|c|}{$\begin{array}{c}\text { Canadian Institute of Forestry - Institut forestier du Canada } \\
\text { Schedule C } \\
\text { Statement of Operations - Annual General Meetings } \\
\text { for the year ended June 30, 1998 }\end{array}$} \\
\hline & 1998 & & 1997 \\
\hline \multicolumn{4}{|l|}{ Revenue } \\
\hline AGM - 1996 & $\$$ & $\$$ & 7,866 \\
\hline \multicolumn{4}{|l|}{ Expenditures } \\
\hline AGM - 1996 & $\$$ & $\$$ & 2,865 \\
\hline AGM - 1997 & 8,319 & & - \\
\hline AGM - 1998 & 5,520 & & - \\
\hline \multirow[t]{2}{*}{ Directors' travel } & 10,350 & & 4,702 \\
\hline & $\$ 24,189$ & $\$$ & 7,567 \\
\hline \multicolumn{4}{|c|}{ (Net cost) Net surplus of operating } \\
\hline Annual General Meetings & $\$(24,189)$ & $\$$ & 299 \\
\hline
\end{tabular}

Canadian Institute of Forestry - Institut forestier du Canada Schedule D

Statement of Operations - Miscellaneous

\begin{tabular}{|c|c|c|}
\hline & 1998 & 1997 \\
\hline \multicolumn{3}{|l|}{ Revenue } \\
\hline Rings/Jewellery & $\$ 2,797$ & $\$ 2,859$ \\
\hline Novelty items & 660 & 375 \\
\hline Miscellaneous & 1,909 & 3,844 \\
\hline \multirow[t]{2}{*}{ Letterhead } & 40 & 40 \\
\hline & $\$ 5,406$ & $\$ 7,118$ \\
\hline \multicolumn{3}{|l|}{ Expenditures } \\
\hline Medals/Awards & $\$ 1,260$ & $\$ 2,228$ \\
\hline Rings/Jewellery & 8,189 & 6,756 \\
\hline Novelty items & 458 & 2,138 \\
\hline Miscellaneous & 1,180 & 2,347 \\
\hline \multirow[t]{2}{*}{ Certificates } & 435 & 350 \\
\hline & $\$ 11,522$ & $\$ 13,819$ \\
\hline Net cost of Miscellaneous & $\$ 6,116$ & $\$ 6,701$ \\
\hline
\end{tabular}
for the year ended June 30, 1998 


\begin{tabular}{|c|c|c|c|c|c|}
\hline \multicolumn{6}{|c|}{$\begin{array}{c}\text { Canadian Institute of Forestry/Institut Forestier du Canada } \\
\text { Operating Budget }\end{array}$} \\
\hline & $\begin{array}{c}\text { Actual } \\
1994-95\end{array}$ & $\begin{array}{c}\text { Actual } \\
1995-96\end{array}$ & $\begin{array}{c}\text { Actual } \\
1996-97\end{array}$ & $\begin{array}{c}\text { Actual } \\
1997-98\end{array}$ & $\begin{array}{c}\text { Proposed Budget } \\
1998-99\end{array}$ \\
\hline \multicolumn{6}{|l|}{ Revenues } \\
\hline Members Dues & 199,385 & 205,826 & 197,146 & 197,542 & 195,000 \\
\hline Sustaining Members & 22,262 & 22,714 & 21,225 & 20,530 & 20,000 \\
\hline Interest & 3,826 & 3,816 & 4,454 & 2,973 & 3,000 \\
\hline Life Insurance & 1,397 & 441 & 1,003 & 45 & 750 \\
\hline Special Projects (schedule A) & 0 & 7.748 & -2.093 & $-5,724$ & -1.000 \\
\hline Total & 226,870 & 240,545 & 221,735 & 215,366 & 217,750 \\
\hline \multicolumn{6}{|l|}{ Expenditures } \\
\hline Salaries & 109,359 & 78,381 & 92,207 & 97,078 & 99,000 \\
\hline Travel Exec. Comm. & 2,251 & 0 & 933 & 2,288 & 2,000 \\
\hline Travel Exec. Director & 7,281 & 5,352 & 10,377 & 10,432 & 10,000 \\
\hline Rent & 16,276 & 15,016 & 15,167 & 15,051 & 15,100 \\
\hline Hospitality & 1,898 & 1,832 & 264 & 2,061 & 2,000 \\
\hline Translatation & 755 & 911 & 1,513 & 479 & 1,000 \\
\hline Office Expenses & 16,305 & 12,700 & 15,448 & 13,834 & 15,000 \\
\hline On-Line Services & 1,069 & 575 & 3,650 & 6,403 & 4,000 \\
\hline Office Equipment & 0 & 0 & 0 & 2,798 & 3,000 \\
\hline Mail/Courier & 8,039 & 10,357 & 9,885 & 8,307 & 10,000 \\
\hline Accreditation & 613 & 7,206 & 9,376 & 7,645 & 9,000 \\
\hline Audit & 5,052 & 4,367 & 4,877 & 5,116 & 5,200 \\
\hline Telephone/Fax & 4,951 & 5,485 & 8,052 & 6,290 & 7,000 \\
\hline Print & 7,826 & 5,711 & 5,366 & 6,177 & 5,000 \\
\hline Bank & 538 & 441 & 506 & 568 & 500 \\
\hline Bad debts & 0 & 0 & 0 & 822 & 0 \\
\hline Forestry Chronicle (schedule B) & 35,495 & 1,974 & $-10,400$ & 6,309 & 9,100 \\
\hline AGM (schedule C) & 22,105 & 16,511 & -299 & 24,189 & 25,000 \\
\hline Miscellaneous (schedule D) & 16.583 & 5.017 & 6.701 & $\underline{6.116}$ & $\underline{4.900}$ \\
\hline Total & 256,396 & 171,836 & 173,623 & 221,963 & 226,800 \\
\hline \multicolumn{6}{|l|}{ Revenues/Expenditures } \\
\hline Revenue & 226,870 & 240,545 & 221,735 & 215,366 & 217,750 \\
\hline Expenditures & $\underline{256.396}$ & 171.836 & 173.623 & $\underline{221.963}$ & 226.800 \\
\hline Balance & $-29,526$ & 68,709 & 48,112 & $-6,597$ & $-9,050$ \\
\hline
\end{tabular}

\begin{tabular}{|c|c|c|c|c|c|}
\hline \multicolumn{6}{|l|}{ Schedule A - Special Projects } \\
\hline & $\begin{array}{c}\text { Actual } \\
1994-95\end{array}$ & $\begin{array}{c}\text { Actual } \\
1995-96\end{array}$ & $\begin{array}{c}\text { Actual } \\
1996-97\end{array}$ & $\begin{array}{c}\text { Actual } \\
1997-98\end{array}$ & $\begin{array}{r}\text { Proposed } \\
1998-99\end{array}$ \\
\hline China-CIDA & 15,808 & 27,800 & 42,899 & 14,470 & 0 \\
\hline FAO - CIDA & 0 & 23,400 & 0 & 0 & 0 \\
\hline IWG - CIDA & 0 & 20,163 & 0 & 23,000 & 23,000 \\
\hline Forest Communicators Conf. & 0 & 2,000 & 0 & 0 & 0 \\
\hline Canadian Criteria and Indicators & 0 & 4,000 & 2,000 & 0 & 0 \\
\hline Forest Pest Management Caucus & 0 & 3,350 & 1,663 & 1,109 & 0 \\
\hline New and Old Projects & 0 & 0 & 0 & 0 & 0 \\
\hline Total & $\overline{15,808}$ & $\overline{82,639}$ & $\overline{61,433}$ & $\overline{39,029}$ & $\overline{23,000}$ \\
\hline \multicolumn{6}{|l|}{ Expenditures } \\
\hline CFPFA & 0 & 369 & 2,495 & 353 & 0 \\
\hline OPFA/CIF Conference & 0 & 1,507 & 13,028 & 0 & 0 \\
\hline Canadian Criteria and Indicators & 0 & 3,263 & 664 & 0 & 0 \\
\hline Task Force Project & 0 & 0 & 2,778 & 3,712 & 1,000 \\
\hline Forest Pest Management Caucus & 0 & 3.350 & 1,662 & 1.109 & 0 \\
\hline Total & $\overline{15,808}$ & $\overline{74,891}$ & 63,526 & 44,753 & 24,000 \\
\hline Net Balance & 0 & 7,748 & $-2,093$ & $-5,724$ & $-1,000$ \\
\hline
\end{tabular}


Schedule B - Forestry Chronicle

\begin{tabular}{|c|c|c|c|c|c|}
\hline & $\begin{array}{c}\text { Actual } \\
1994-95\end{array}$ & $\begin{array}{c}\text { Actual } \\
1995-96\end{array}$ & $\begin{array}{c}\text { Actual } \\
1996-97\end{array}$ & $\begin{array}{c}\text { Actual } \\
1997-98\end{array}$ & $\begin{array}{c}\text { Proposed } \\
1998-99\end{array}$ \\
\hline \multicolumn{6}{|l|}{ Revenue } \\
\hline Advertising & 43,682 & 46,090 & 53,001 & 50,489 & 50,000 \\
\hline Page Charges & 39,888 & 39,155 & 32,010 & 31,555 & 30,000 \\
\hline Reprints/Colour Production & 30,567 & 22,054 & 16,774 & 18,671 & 10,000 \\
\hline Subscriptions & 35.275 & 34,145 & 33.245 & 31.462 & 33.000 \\
\hline Total & 149,412 & 141,444 & 135,030 & 132,177 & 123,000 \\
\hline \multicolumn{6}{|l|}{ Expenditures } \\
\hline Editors & 14,920 & 14,720 & 15,110 & 15,250 & 15,000 \\
\hline Production manager & 10,800 & 7,550 & 7,420 & 8,540 & 8,000 \\
\hline Print & 109,566 & 75,738 & 63,860 & 74,026 & 70,000 \\
\hline Mail & 15,126 & 15,385 & 15,185 & 15,846 & 15,500 \\
\hline Reprints & 15,008 & 10,890 & 2,067 & 1,728 & 2,000 \\
\hline Miscellaneous & 4,150 & 5,611 & 7,570 & 7,824 & 7,500 \\
\hline Advertising Sales & 15.337 & 13.524 & 13.418 & 15.272 & 14,100 \\
\hline Total & 184,907 & 143,418 & 124,630 & 138,486 & 132,100 \\
\hline Net Balance & $-35,495$ & $-1,974$ & 10,400 & -6309 & $-9,100$ \\
\hline
\end{tabular}

Schedule C-AGM

\begin{tabular}{|c|c|c|c|c|c|}
\hline & $\begin{array}{c}\text { Actual } \\
1994-95\end{array}$ & $\begin{array}{c}\text { Actual } \\
1995-96\end{array}$ & $\begin{array}{c}\text { Actual } \\
1996-97\end{array}$ & $\begin{array}{c}\text { Actual } \\
1997-98\end{array}$ & $\begin{array}{c}\text { Proposed } \\
1998-99\end{array}$ \\
\hline \multicolumn{6}{|l|}{ Revenue } \\
\hline AGM present year & 39,682 & 26,093 & 4,366 & 0 & 0 \\
\hline AGM following year & 6,535 & 40 & 0 & 0 & 0 \\
\hline Advances & -6.472 & 7.000 & $\underline{3.500}$ & $\underline{0}$ & $\underline{0}$ \\
\hline Total & $\overline{39,745}$ & $\overline{33,133}$ & 7,866 & 0 & 0 \\
\hline \multicolumn{6}{|l|}{ Expenditures } \\
\hline Director Travel & 11,765 & 8,050 & 4,702 & 10,350 & 9,000 \\
\hline AGM Present year & & 5,888 & 0 & 5,520 & 15,000 \\
\hline Travel Other/Misc. & 13,387 & 4,982 & 2,865 & 7,319 & 0 \\
\hline Registrations & 28,520 & 21,416 & 0 & 0 & 0 \\
\hline AGM Following Year & 8,178 & 8,308 & 0 & 0 & 0 \\
\hline Student Fund & 0 & 1.000 & 0 & 1.000 & 1.000 \\
\hline Total & 61,850 & 49,644 & 7,567 & $\overline{24,189}$ & 25,000 \\
\hline Net Balance & $-22,105$ & $-16,511$ & 299 & $-24,189$ & $-25,000$ \\
\hline
\end{tabular}

Schedule D - Miscellaneous

\begin{tabular}{|c|c|c|c|c|c|}
\hline & $\begin{array}{c}\text { Actual } \\
1994-95\end{array}$ & $\begin{array}{c}\text { Actual } \\
1995-96\end{array}$ & $\begin{array}{c}\text { Actual } \\
1996-97\end{array}$ & $\begin{array}{c}\text { Actual } \\
1997-98\end{array}$ & $\begin{array}{c}\text { Proposed } \\
1998-99 \\
\end{array}$ \\
\hline \multicolumn{6}{|l|}{ Revenue } \\
\hline Rings/Jewellery & 2,735 & 2,581 & 2,859 & 2,797 & 2,500 \\
\hline Novelty Items & 710 & 479 & 375 & 660 & 500 \\
\hline Miscellaneous & 6,009 & 2,462 & 3,844 & 1,909 & 3,500 \\
\hline Christmas Cards & 0 & 913 & 0 & 0 & 0 \\
\hline Letterhead & 80 & 40 & 40 & 40 & 0 \\
\hline Booksales & 373 & 0 & 0 & 0 & 0 \\
\hline Total & $\overline{9,907}$ & $\overline{6,475}$ & $\overline{7,118}$ & $\overline{5,406}$ & 6,500 \\
\hline \multicolumn{6}{|l|}{ Expenditures } \\
\hline Medals/Awards & 1,472 & 2,156 & 2,228 & 1,260 & 2,200 \\
\hline Rings/Jewellery & 6,315 & 6,295 & 6,756 & 8,189 & 6,800 \\
\hline Miscellaneous & 17,179 & 2,149 & 2,347 & 1,180 & 2,000 \\
\hline Novelty Items & 838 & 259 & 2,138 & 458 & 0 \\
\hline Certificates & 686 & 380 & 350 & 435 & 400 \\
\hline Christmas Cards & 0 & 253 & 0 & 0 & 0 \\
\hline Total & $\overline{26,490}$ & $\overline{11,492}$ & $\overline{13,819}$ & $\overline{11,522}$ & $\overline{11,400}$ \\
\hline Net Balance & $-16,583$ & $-5,017$ & $-6,701$ & $-6,116$ & $-4,900$ \\
\hline
\end{tabular}




\begin{tabular}{|c|c|c|c|}
\hline \multicolumn{4}{|l|}{ Balance Sheet } \\
\hline & $1995-96$ & $1996-97$ & 1997-98 \\
\hline \multicolumn{4}{|l|}{ Assets } \\
\hline Accounts Receivable & $\$ 20,218.00$ & $\$ 21,739.00$ & $\$ 835.41$ \\
\hline Cash in bank & $31,240.00$ & $30,115.00$ & $50,046.14$ \\
\hline Investments - Short term & $132,552.00$ & $125,714.00$ & $60,000.00$ \\
\hline Reserves & & 36.837 .00 & 69.908 .30 \\
\hline Total & $184,010.00$ & $214,405.00$ & $180,789.85$ \\
\hline \multicolumn{4}{|l|}{ Liabilities } \\
\hline Accounts Payable & $\$ 15,730.00$ & $\$ 2,803.00$ & $\$(117.82)$ \\
\hline Dues received in advance & $118,584.00$ & $93,991.00$ & $75,066.18$ \\
\hline Section Dues Payable & - & $9,802.00$ & $9,264.15$ \\
\hline Deferred Revenue & 12.860 .00 & 23.411 .00 & 0 \\
\hline Total & $\$ 147,174.00$ & $\$ \overline{130,007.00}$ & $\$ 84,212.51$ \\
\hline Assets over Liabilities & $\$ 36,836.00$ & $\$ 84,398.00$ & $\$ 96,577.34$ \\
\hline \multicolumn{4}{|l|}{ Capital } \\
\hline Balance of funds beginning & $\$(31,872.00)$ & $\$ 36,837.00$ & $\$ 84,949.00$ \\
\hline Current Earnings & 68.709 .00 & 48.112 .00 & $(6.597 .37)$ \\
\hline Total & $\$ 36,837.00$ & $\$ 84,949.00$ & $\$ 78,351.63$ \\
\hline
\end{tabular}

\begin{tabular}{|c|c|c|}
\hline \multicolumn{3}{|c|}{$\begin{array}{l}\text { Forestry Awareness in Canada Trust } \\
\text { Statement of Operations and Surplus } \\
\text { for the Year Ended June 30, } 1998\end{array}$} \\
\hline & 1998 & 1997 \\
\hline \multirow{4}{*}{$\begin{array}{l}\text { Revenues } \\
\text { Donations } \\
\text { Other income }\end{array}$} & & \\
\hline & $\$ 756$ & $\$ 789$ \\
\hline & 31 & 46 \\
\hline & 787 & 835 \\
\hline \multicolumn{3}{|l|}{ Expenditures } \\
\hline & 2,500 & 4,000 \\
\hline \multirow[t]{2}{*}{ Miscellaneous } & 254 & 83 \\
\hline & 2,754 & 4,083 \\
\hline $\begin{array}{l}\text { Excess of } \\
\text { (expenditures over revenue) }\end{array}$ & $(1,967)$ & $(3,248)$ \\
\hline Surplus - beginning of year & 3,750 & 6,998 \\
\hline Surplus - end of year & $\$ 1,783$ & $\$ 3,750$ \\
\hline
\end{tabular}

\section{Auditor's Report}

\section{To the Trustees of the Forestry Awareness In Canada}

Trust

We have audited the balance sheet of the Forestry Awareness In Canada Trust as at June 30, 1998 and the statement of operations and surplus for the year then ended. These financial statements are the responsibility of the Trust's management. Our responsibility is to express an opinion on these financial statements based on our audit.

We conducted our audit in accordance with generally accepted auditing standards. Those standards require that we plan and perform an audit to obtain reasonable assurance whether the financial statements are free of material misstatement. An audit includes examining, on a test basis, evidence supporting the amounts and disclosures in the financial statements. An audit also includes assessing the accounting principles used and significant estimates made by management, as well as evaluating the overall financial statement presentation.

In our opinion, these financial statements present fairly in all material respects, the financial position of the Institute as at June 30, 1998 and the results of its operations for the year then ended in accordance with generally accepted accounting principles.

Ottawa, July 27, 1998

Vaillancourt \& Lupinski Chartered Accountants

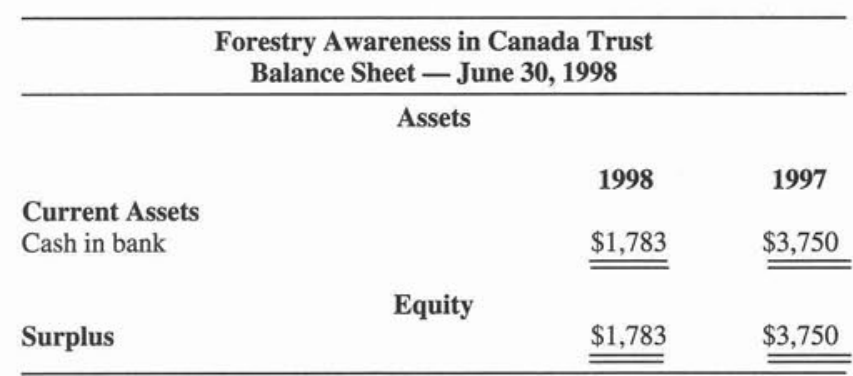

\section{Report of the Membership Committee}

The attached Table 1 provides a summary of membership from 1987 to 1998. As indicated, membership has increased in $1997-98$ by $1.9 \%$. The numbers for $1997 / 98$ are as of June 30, 1998 which are consistent with the trend of the last six years. This would include new or renewing members that joined in the last six months for the 1997/98 fiscal year.

During the 1997/98 year, CIF/IFC extended its budgeted goal of $\$ 190000$ by $\$ 7541.00$. Membership in the active category had been steadily declining for the last eight years, but this year has shown an increase of 146 members or $9.29 \%$ in part due to a voluntary joint dues option with the Association of Registered Professional Foresters Association of British Columbia and joint dues from the Newfoundland CIF/RPF program. The student category decreased by $1.7 \%$ as many of our former student members became full active members. Student membership is $\$ 21.00$ and a promotional student package was offered at the ring ceremonies; however, only four students took advantage of the reduced dues. Retired paying members have slowly increased for the last few years; however, there was a decline this year as some of our retired members chose to resign from the CIF/IFC. Various reasons were given, including health deterioration, advancing years, no further interest in events, recent research, etc. The non-paying retired members have been declining since that category was grandfathered in the late 1980s early 90 s. This year we removed all of the members in this classification who have not paid Section Dues.

Corporate Sustaining Membership is 56 down from 63 last year. We have contacted many former Corporate Members asking them to consider rejoining CIF/IFC.

The "Stand and Be Recognized" membership brochure was adapted to the Internet site, and several applications were received through this medium. The "recruit three get yours free" deal was offered again to members. 
Many sections were active throughout the year visiting colleges and universities, promoting the CIF/IFC to students and professors. Several sections also contacted non-renewing members and asked them to reconsider their membership.
The Recruiting prize for $1997 / 98$ goes to Klondike Section with an increase of $75 \%$ in membership over 96/97.

Respectfully submitted by: Roxanne Comeau, R.P.F. July 1, 1998

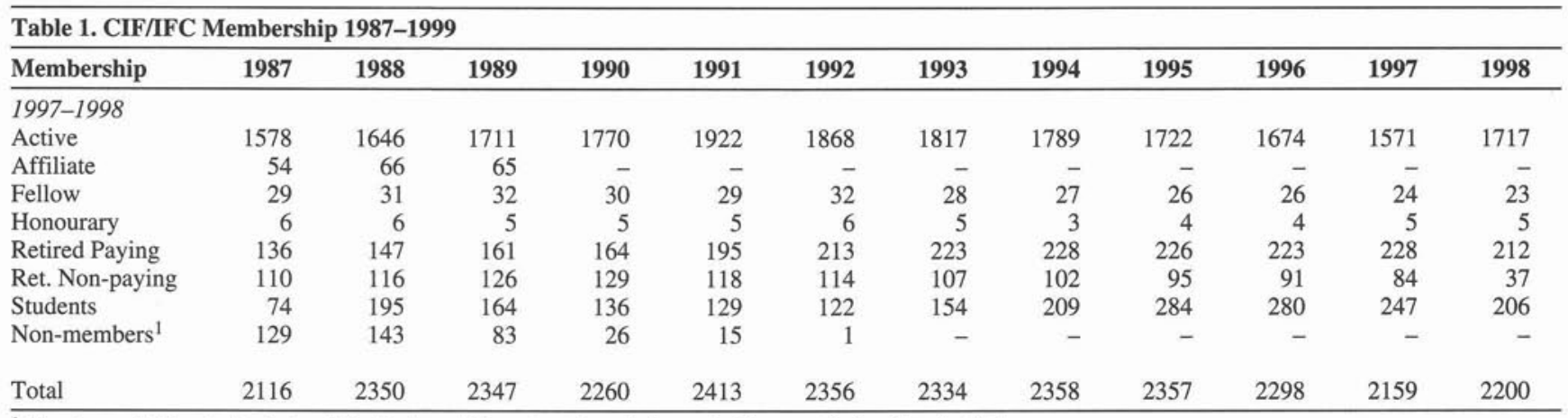

${ }^{1}$ Members of Alberta Registered Professional Foresters Association who have not joined the Institute.

Note: counts for (Jan - 1986, 1987, 1988), (March - 1989, 1990), (June 30 - 1991, 1992, 1993, 1994, 1995, 1996, 1997, 1998)

\section{Report of the Nominating Committee}

The 1997/98 Nominating Committee consisted of:

$$
\begin{aligned}
& \text { J. Barker - Chair } \\
& \text { R. Comeau - Secretary }
\end{aligned}
$$

Two nominations were received for the position of $2^{\text {nd }}$ VicePresident for 1998/99. A membership ballot was received and V.J. Nordin and R. Comeau were scrutineers. The Nominating Committee is pleased to announce the following results:

E. Wrangler - assumes the post of President

B. Ferguson - First Vice-President by acclamation

G. Stone - assumes the post of $2^{\text {nd }}$ Vice-President by ballot vote

R. Roberts - Past President

Respectfully submitted by:

J. Barker, Chair of Nominating Committee July 10, 1998

\section{Continuing Forestry Education Program Report}

The Continuing Forestry Education program has now completed its third year. To obtain a "Continuing Forestry Education Certificate" applicants must have completed 150 hours of "approved" CFE activities within a three-year period. The three-year retroactive phase-in period ended in June 1998. In Alberta, Ontario and New Brunswick the program has been adopted by the Registered Professional Foresters Association.

Activities are described in three broad categories recognizing different CFE activities. Credit weight varies with the type of activity, and the "contact hour" is based on one hour of instruction or equivalent. Credit may be claimed for course work.

The three categories are:
Structured learning - minimum 60 contact hours, but one can take all 150 hours in this category. Includes workshops, seminars, conference.

Self-improvement - 90 contact hours maximum, includes attendance at CIF/IFC or business meetings, reading or viewing/listening to related technical forestry material such as The Forestry Chronicle or videos.

Professional Contributions - 60 contact hours maximum, includes giving presentations, writing articles (only when beyond the normal work duties), holding an elected or appointed office in CIF, RPF or allied professional organizations.

As of June 30, 1998:

$\begin{array}{cl}\text { Number } & \text { No. of Certificates } \\ 76 & \text { one certificate } \\ 41 & \text { two certificates } \\ 26 & \text { three certificates }\end{array}$

Total 143 individuals

The names of the individuals were published in the Forestry Chronicle.

Respectfully submitted by: Roxanne Comeau, CIF/IFC Executive Director July 1, 1997

\section{Report of the Awards Committee}

Chairman - R. Roberts

Members - Executive Committee

Secretary - R. Comeau

The Awards Committee is the Executive Committee that sits as a special committee.

Recipients for following awards were as follows: Canadian Forestry Achievement Ted Boswell Dirk Brinkman 
Canadian Forestry Scientific

Achievement

James M. Kitz

International Forestry Achievement

Canadian Forest Management Group

Achievement

\section{Brian Stocks \\ Steve Ginnish \\ Mike Apsey}

Scouts Canada

The Schlich Memorial Prize was awarded to Jason

Zimmerman, University of British Columbia

There were 23 Gold Medal Winners:

\section{British Columbia}

Cariboo Section

New Caledonia

University of Northern

British Columbia

Okangan Section

Selkirk

Vancouver Section

British Columbia Institute of Technology

University of British Columbia

Vancouver Island Section

Malaspina

\section{Alberta}

Rocky Mountain Section

Northern Alberta Institute of Technology

University of Alberta

\section{Saskatchewan}

Saskatchewan Section

Saskatchewan Institute of Applied

Science and Technology
Joleen Warmerdam

Amber Dereshkevich

Stacey Rene Bryam

James Webb

D. Bradley Collins

Krishna Payne

Wayne Sidwell

Stacy Wowk

Russell Olson

\section{Ontario}

Northwestern Ontario Section

Lakehead Forestry School

Julia Jones

Lakehead University

Central Ontario Section

College Boreal

Sault College

Joel Girard

Dean Assinewe

Kelly McMahon

Southern Ontario Section

Sir Sandford Fleming

Ottawa Valley Section

Algonquin College of Applied Arts and Technology

La Cité Collegiale

Sharon Lebaron

Steve Innes

Jean Renaud

\section{Quebec}

Orleans Section

Abitibi-Temiscaming Baie-Comeau Philippe Marchand

Chicoutimi

Gaspesie des Iles

Rimouski

Sainte-Foy

Sainte-Félicien

Université Laval (November 1998)

Cathy Lefrancois

Michael Pitre

Martin Ladouceur

Mathieu Robitaille

Carlo Gagliardi

\section{New Brunswick}

Maritime Section

Maritime Forest Ranger School

Université de Moncton

University of New Brunswick

Rodney Smith

Mélanie Roy

Geoff Clarke

\section{Newfoundland}

Newfoundland Section

College of The North Atlantic Keith Smith

Roy Sutton was nominated by Central Ontario Section for consideration as a Fellow Member

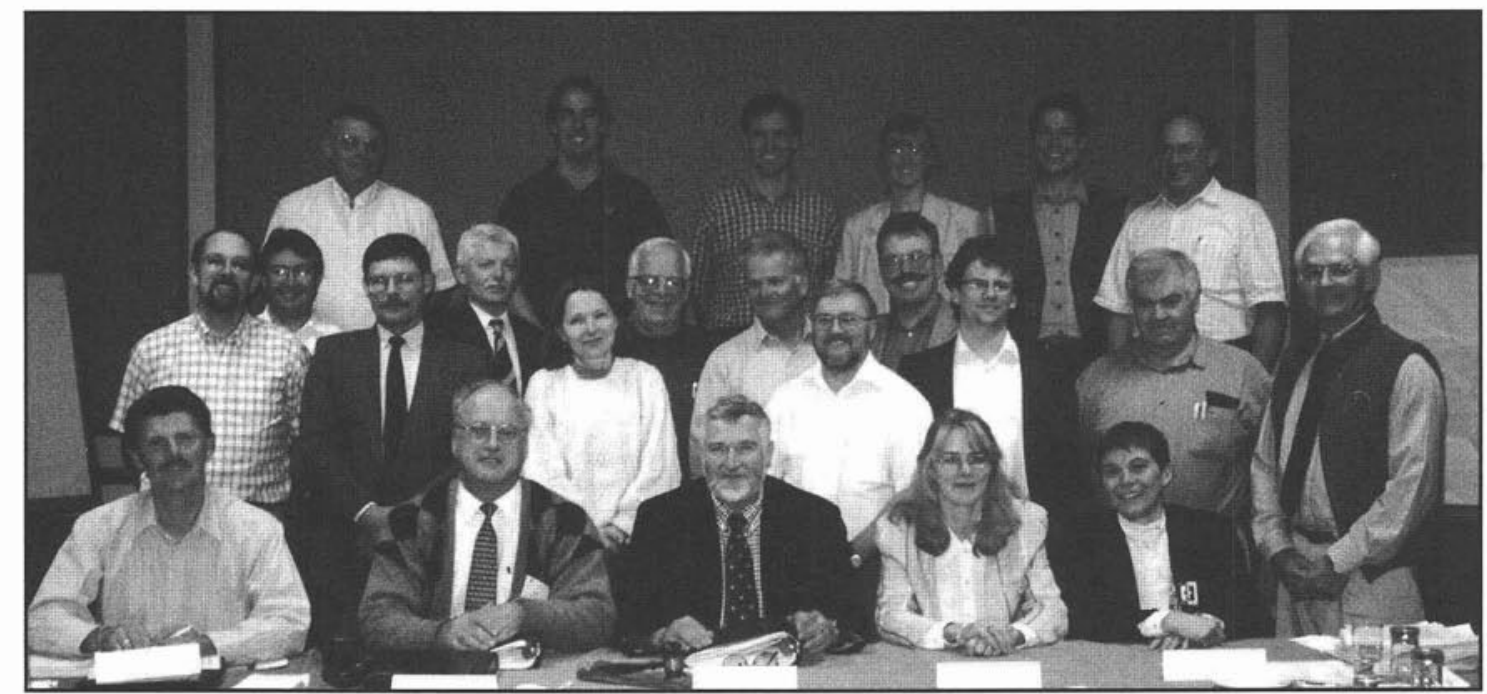

CIF/IFC

$1997 / 1998$

Board of Directors 
Frank Oberle was nominated by Cariboo Section for consideration as an Honourary Member

Nine members were admitted to the Golden Year Club in 1998:

R.F. Fytche

Walter J. Giles

A. D. Hall

D.V. Love

J. L Mennill

V. J. Nordin

G. A. Patterson

F. C. Robinson

O. A. Waluk

Forester Rings were presented to 382 graduating students:

University of British Columbia

University of Northern British Columbia

Université Laval

University of New Brunswick

University of Alberta

Lakehead University

Université Moncton

Six Tree of Life Awards were presented: 1998

Girvan Harrison

Kenny McGinn

MR

Mark Clark

MR

Robert J. Day

CR

Robert Galloway

J.R.M. "Mack" Williams

NW

NO

SO

Klondike Section receives the "Recruiting Prize" for increase in their membership by $75 \%$ during the $1997 / 98$ year.

Respectfully submitted by Roxanne Comeau, CIF/IFC Executive Director July 1, 1998

\section{Staffing 1997/98 Report}

Roxanne Comeau, Executive Director; Cherry Maxwell, Office Manager; Susan Easterman Membership/Forestry Chronicle Advertising Sales; Vidar Nordin, Editor; Brian Haddon, Research Editor and Tim Fenton, Production Manager. Darwin Burgess "retired" from the position of co-editor in December 1997.

\section{Future Meetings \\ 1999 Banff, Alberta \\ 2000 Corner Brook, Newfoundland \\ 2001 Vancouver, British Columbia}

\section{Report of Forest Science and Technology Board}

The CIF/IFC Directors and Working Group Chairs met at the 1998 Directors' Meeting in Prince George to discuss the working groups and activity. During the year, the Working Group chairs met via conference call twice.

Several position papers were revised during the year, three from the Ecology working group - Old Growth Forest, Clearcutting, and Climate Change. The International Working Group sponsored speakers from developing countries to the 1996 AGM in Thunder Bay and the 1997 AGM in Prince George. As well, the International Working Group assisted the CIF/IFC in the Chinese Society of Forestry and CIF/IFC exchange of experts.

Submitted by R. Comeau July 1, 1998

\section{Standing Committee on Restructuring Year 1 - Progress Report 1997/98}

1997 Resolution "Establish a standing committee to research restructuring to lead to changes to the Institute mandate to serve both the society and the membership".

1. Terms of Reference developed which set out:

a) Principles - continue to Honour

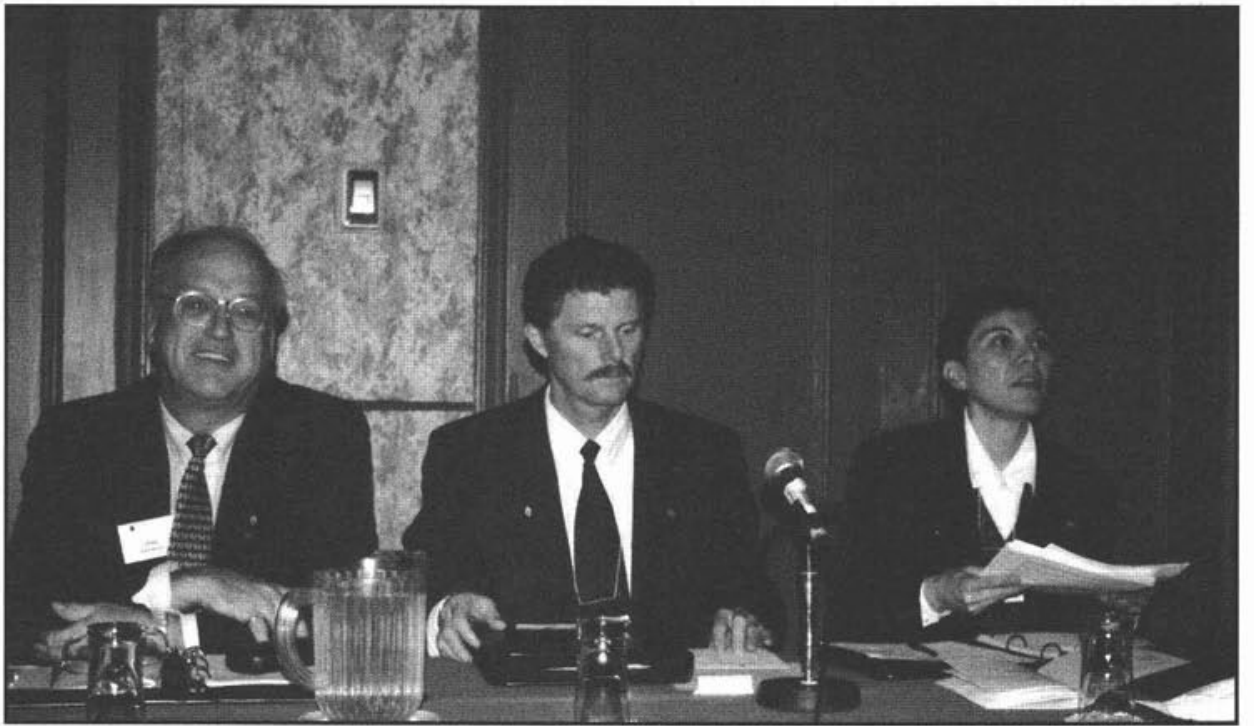

1997/1998 CIF/IFC Executive. Left to Right: John Barker, Past President; Bruce Ferguson, 2nd Vice-President; Evelynne Wrangler, 1 st Vice-President and President Elect at the CIF/IFC business session (Ralph Roberts missing from photo). 
b) Objectives of a potential new organization model

c) A timeframe for restructuring review that ensured membership discussion and Board approval on each development toward a preferred model within 3 years

d) Create a Standing Committee of diverse representation from within CIF/IFC membership

2. Chair/Executive Director met with Agricultural Institute of Canada to explore their model's benefits/problems.

3. Committee created upon recommendations

Chair - 2nd VP - Bruce Ferguson (1997/98)

Sue Michalsky

Jean-Pierre Dansereau

Jim Cayford (ex officio reviewer)

Roxanne Comeau (ex officio member)
5. Other organizational models distributed for review and review of former CIF/IFC Reports on Restructuring

6. Issues to address identified by Committee

- Quebec membership and ties with OIFQ

- Separating mandate from governance

- Ensuring ample opportunity for discussion

- Placing more emphasis on non-fee revenue generation

- Uniting voices nationally without losing CIF/IFC identity

7. Review results to be reported at AGM 1999 for Board recommendations on how and where to proceed.

4. Committee Approval of Terms of Reference with amendments.

Respectfully submitted

Bruce Ferguson R.P.F.

2nd Vice President

October 3, 1998

\title{
Canadian Institute of Forestry / Institut Forestier du Canada
}

\author{
90th Annual General Meeting \\ Citadel Ottawa Hotel \\ Ottawa, Ontario \\ October 5, 1998 and final resolutions on October 8, 1998 \\ MINUTES
}

Chairperson: Ralph Roberts

Platform: John Barker, Bruce Ferguson, Evelynne Wrangler, Roxanne Comeau.

\section{Opening}

Ralph Roberts called the 90th CIF/IFC Annual General Meeting to order at 10:00 a.m. and welcomed the members. A quorum was determined.

Ralph Roberts noted the special 90th Anniversary project of the display of the all the Presidents of the Institute. These photos will be on display for the duration of the conference and will then be on permanent display at the CIF/IFC office in Ottawa.

2. Deceased Members

A.V. (Bill) Backman

Gordon W. Brown

Robert I. Clarke

Braham W. Griffith

John H. Godden

Philip G. Haddock

John L. Ladell

Gary D. McKellar

Warren S. Moore

Zoltan J. Nemeth

Frank T. Pendl
Sheldon Willigar

R. Roberts also mentioned colleagues who have passed away this year who were not members at the time of their passing but who have contributed to forestry in Canada. They are: Turk Bailey, Steve Zoltai, Dan Brink.

A moment of silence was held in respect for members and individuals that had passed away since the last annual meeting.

3. Approval of Minutes of the 89th Annual General Meeting in Prince George, British Columbia.

Moved (Delaney, Kayll) that the Minutes be accepted.

Carried.

4. Officers and Committee Reports

R. Roberts noted the officers' and committee reports in the AGM booklets and highlighted activities from the year.

\section{Awards}

Ralph Roberts noted the awards recipients for this year are noted in the Booklet and was pleased to announce the following:
Canadian Forestry Achievement - Dirk Brinkman and Ted Boswell Canadian Forestry Scientific Achievement - Brian Stocks

International Forestry Achievement - Mike Apsey

James M. Kitz - Stephen Ginnish Canadian Forest Management Group Achievement - Scouts Canada

6. Report of the Banner Issue for 1997-98.

Evelynne Wrangler presented the Action Plan and Banner Issue for 1998-99.

The Banner issue theme will be Stewardship through Partnership

Bruce Devitt remarked on partnership and action items and how they are similar to actions indicated 20 years ago, and asked if some of the Board members present could comment on the Banner Issue and Action Plan. Several members of the Board provided comments.

7. Finance Committee Report. Moved (Kayll, Devitt) that the Finance Committee report be received.

Carried. 


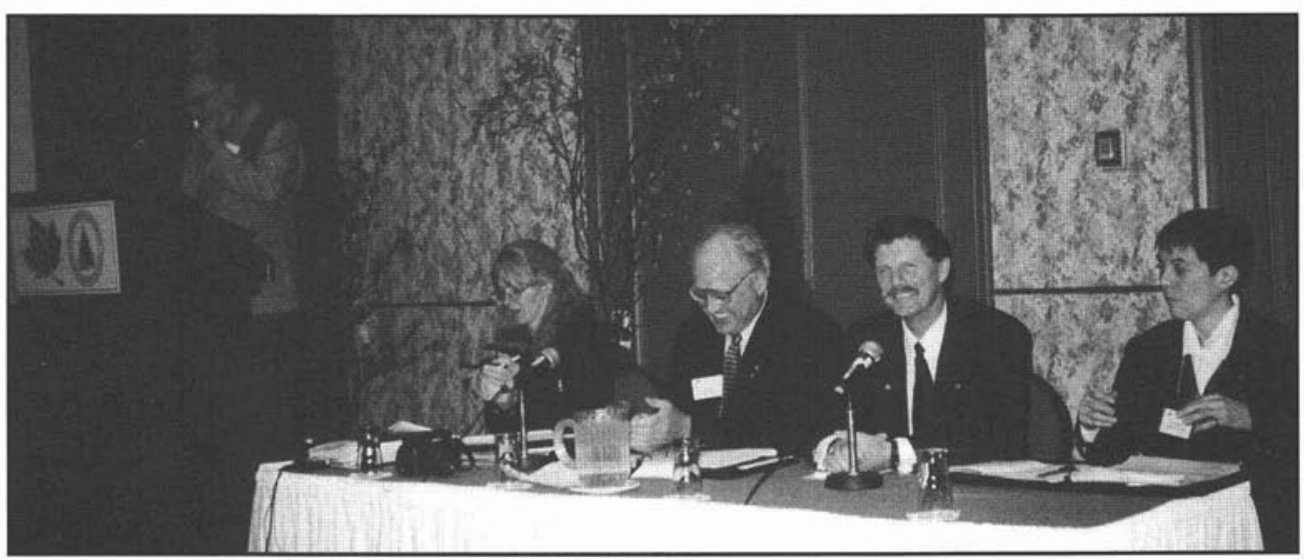

The CIF/IFC business session. $L$ to R: Ralph Roberts,

President; Roxanne Comeau, Executive Director; John Barker, Past President; Bruce Ferguson, 2nd Vice President; Evelynne Wrangler, 1st Vice President and President Elect.

\subsection{Auditor's Report.}

Roxanne Comeau reviewed the Auditor's report for the membership. Moved (Kayll, Hoyt) that the Auditor's report be accepted as distributed.

Carried.

\subsection{Budget 1997-98}

Roxanne Comeau reviewed the budget presented .

Moved (Kayll, MacLaughlan) that the Budget be accepted.

\section{Carried.}

\subsection{Appointment of Auditors}

Moved (Gelinas, Stone) that Vaillancourt and Lupinski be appointed as CIF/IFC Auditors for 1998/99 fiscal year.

Carried.

\subsection{National Membership Dues}

Moved (Hoyt, Krystofiak) that the membership dues will not increase in 1999/2000.

Active - $\$ 131.00$

New $\quad-\$ 93.00$

Student - \$21.00

Retired - \$ 42.00

Sustaining - \$ 44.00 (minimum)

Corporate - \$275.00 (minimum)

Carried.

7.5 Forestry Chronicle Subscription and Advertising Rates.

Moved (Hoyt, Delaney) that there will not be an increase in Forestry Chronicle rates in 1999.

Single User Canadian

$\$ 79.00$

Multi User Canadian

$\$ 87.00$

Single User Foreign

$\$ 92.00$ US

Multi User Foreign

\section{$\$ 105.00$ US}

Carried

\section{Staff Report}

The members expressed appreciation to the CIF/IFC staff.
9. Future Meetings

1999 - Banff, Alberta.

D. Gelinas noted Banff will host the

91st AGM. October 3- October 8, 1999.

2000 - David Cheeks noted Cornerbrook, Newfoundland will host CIF/IFC's 92nd AGM in August 2000.

2001 - David Lloyd noted that Vancouver will host the 2001 meeting.

\section{Resolutions}

98-10.1 Forestry Education programs Whereas: In several provinces, inadequate government funding and imposition of arbitrary caps are constraining delivery of Forest Resource Stewardship Education Programs.

Whereas: These inadequacies have a potentially large deleterious impact on our ability to maintain and develop professional capability to deliver Sustainable Forest Management and to maintain Canada's international commitments in this area.

\section{Therefore be it resolved that:}

The Executive and Membership of the CIF/IFC, in partnership with other forestry associations and organizations bring to the attention of those who have a responsibility for financial support, the imperative needs of Canada's forestry education programs.

Moved: Bruce Devitt

SECONDED: Jim Kayll

\section{Carried.}

\section{8-10.2 Retired membership}

Whereas: It is important for the CIF/IFC to maintain a strong and energetic membership of both active and retired mem- bers who have much to offer in terms of expertise and knowledge in forestry and related resource issues and;

Whereas: in the next decade there will be an ever-increasing number of retirees from the forestry and related professions to retain or recruit as members and;

Whereas: Potential retired members without fifteen years prior CIF/IFC membership and significantly reduced income, are required to pay the active membership fee of $\$ 131.00$ instead of the retired membership fee of $\$ 42.00$ and;

Whereas: the CIF/IFC has not adequately defined the term "retired", and will find it awkward to verify the condition "significantly reduced income";

Therefore be it resolved that: the Manitoba section of the CIF/IFC moves that the CIF national executive review the current requirements and dues of the category of retired member, considering the cost of membership, and potential revisions to eligibility requirements such as member's age, years of prior CIF/IFC membership, a sliding scale of dues over increasing years after retirement, and any other reasonable modification

MoveD: Jeff Delaney,

Dave Rannard

SECONDED: Dave Neufeld

Carried.

\section{8-10.3 Ottawa Annual Meeting}

Whereas: The 1998 Annual General Meeting of the Canadian Institute of Forestry/Institut forestier du Canada, held in Ottawa, Ontario in celebration of its 90th Anniversary, has provided mem- 
bers and guests with an excellent technical programme and opportunities to sample the many social amenities of the capital region.

\section{Therefore be it resolved that:}

The delegates of this $90^{\text {th }}$ Annual General Meeting applaud and express their sincere appreciation to the HAMPCO team for planning and conducting a truly superb conference.

Moved: John Barker

SECONDED: Don Gelinas

Carried.

\section{Transfer of Authority}

Ralph Roberts thanked and expressed kind words of appreciation to the Executive Committee and the members. He called on incoming President Evelynne Wrangler. Ms. Wrangler noted her thanks to the past Executive and presented Ralph Roberts with his President of CIF/IFC gold forester ring.

Evelynne Wrangler thanked John Barker as outgoing Past President and welcomed Gordon Stone as the new $2^{\text {nd }}$ Vice President and the new Executive.

\section{The 1998-99 Executive:}

President

Evelynne Wrangler, R.P.F.

Past President

Ralph Roberts, ing. $\mathrm{f}$

$1^{\text {st }}$ Vice President

Bruce Ferguson, R.P.F.

$2^{\text {nd }}$ Vice President

Gordon Stone

Ralph Roberts noted the meeting would be adjourned to Thursday, when final resolutions would be received. (note: these resolutions are noted above).

Adjournment - Thursday, October 9, 1998.

Evelynne Wrangler received the gaval from Ralph Roberts and closed $90^{\text {th }}$ Annual General meeting of the CIF/IFC at 10:30 a.m.

Minutes prepared by Roxanne Comeau, R.P.F. Executive Director October 20, 1998

\section{Canadian Institute of Forestry/Institut forestier du Canada Past Presidents}

\begin{tabular}{llll} 
B.E. Fernow & $(1908)$ & F. Matte & $(1969)$ \\
C. Leavitt & $(1916)$ & W.G. Burch & $(1970)$ \\
E. Wilson & $(1918)$ & J.W. Ker & $(1971)$ \\
M.A. Grainger & $(1924)$ & J.W. Giles & $(1972)$ \\
C.D. Howe & $(1925)$ & G.F. Weetman & $(1973)$ \\
B.F. Avery & $(1927)$ & W. Young & $(1974)$ \\
P.Z. Caverhill & $(1930)$ & W.S. Moore & $(1975)$ \\
G.C. Piché & $(1933)$ & A.B. Anderson & $(1976)$ \\
W.A. Delahey & $(1936)$ & P.E. Boucher & $(1977)$ \\
J.M. Gibson & $(1938)$ & D.R. Redmond & $(1978)$ \\
W.G. Phipps & $(1939)$ & J.H.G. Smith & $(1979)$ \\
F.D. Mulholland & $(1940)$ & W.J.B. Devitt & $(1980)$ \\
L.S. Webb & $(1940)$ & J.G. Garner & $(1981)$ \\
J.D.B. Harrison & $(1943)$ & J.H. Cayford & $(1982)$ \\
R.M. Brown & $(1945)$ & G. Paille & $(1983)$ \\
E. Bruce & $(1947)$ & J.D. Clark & $(1984)$ \\
R.E. Balch & $(1949)$ & J.W. Toovey & $(1985)$ \\
H.W. Beall* & $(1950)$ & J.R. Carrow & $(1986)$ \\
D.A. MacDonald* & $(1950)$ & A.J. Kayll & $(1987)$ \\
K.G. Fensom & $(1951)$ & C. Godbout & $(1988)$ \\
W.A.E. Pepler & $(1953)$ & P.W. Ackhurst & $(1989)$ \\
J.W.B. Sisam & $(1955)$ & C.H. Gairns & $(1990)$ \\
G.W.I. Creighton & $(1957)$ & A. Whidden & $(1991)$ \\
H.J. Hodgins & $(1959)$ & A.A. Rotherham & $(1992)$ \\
L. Besley & $(1961)$ & P.J. Murphy & $(1993)$ \\
R.G. McKee & $(1963)$ & H. Oldham & $(1994)$ \\
K.W. Hearnden & $(1964)$ & S. Tolnai & $(1995)$ \\
D.V. Love & $(1965)$ & J. Barker & $(1996)$ \\
D.I. Crossley & $(1966)$ & R.W. Roberts & $(1997)$ \\
V.J. Nordin & $(1967)$ & & \\
E.S. Fellows & $(1968)$ & * Provisional President & \\
\hline & & &
\end{tabular}

\section{Awards/Prix}

\section{International Forestry Achievement Award}

The International Forestry Achievement Award, first awarded in 1988 recognizes an individual's outstanding contribution towards international forestry development. We are pleased to present this year's award to Mr. Mike Apsey.

After graduating from the University of British Columbia in 1961 with a degree in Forestry, Mr. Apsey joined the B.C. Department of Industrial Development, Trade and Commerce. From there he worked as a senior analyst with MacMillan Bloedel Limited, and later Vice President and Senior Economist with F.L.C. Reed and Associates. Mr. Apsey was the Deputy Minister of the B.C. Ministry of Forests prior to joining the Council of Forest Industries in 1984.

Over the course of his distinguished career, Mr. Apsey has undertaken a

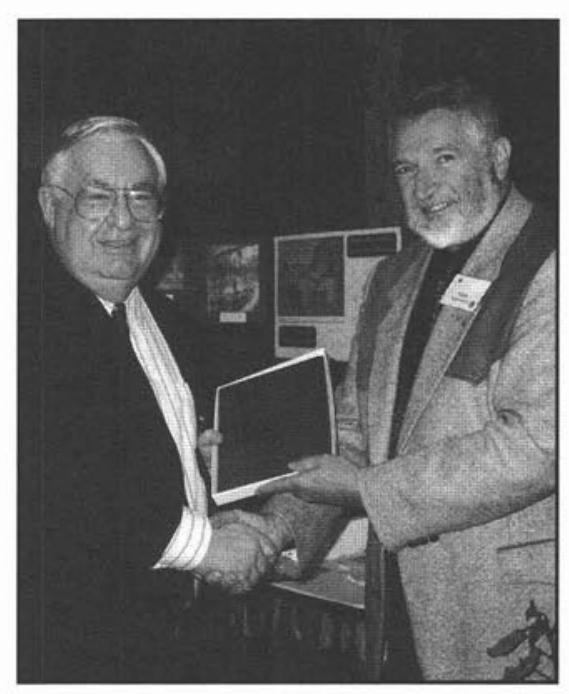

Ralph Roberts presents the International Forestry Achievement Award to Mike Apsey (L). 
number of notable international forestry assignments. He worked extensively on assignment overseas in Turkey, Colombia, Ghana, Honduras and a number of European and other Latin American and African Countries.

On the home front, he conceived and developed a detailed report on global, regional and local social economic and political trends in BC and developed a coalition of differing interest groups to work with the British Columbia Government to develop a Forest Sector Strategy for the Province of B.C. He was a special advisor to the Canadian Government for the development of Canadian position statements on numerous issues relating to UNCED and follow-up to UNCED. Mr. Apsey has served as a member of an International Task Force convened by The World Resources Institute, the World Bank and the United National Development Programme.

He has served on the Boards for the Canadian Forest Industries Council, Pacific Salmon Foundation, B.C. Round Table on the Environment and The

\section{Canadian Forestry Scientific Achievement Award}

The Canadian Forestry Scientific Achievement Award is awarded to recognize an individual's outstanding achievement in forestry research in Canada and who has been active in forest research that has resulted in substantial advances in the science or practice of forestry.

It is with great pleasure that we award Mr. Brian Stocks with the Canadian Forestry Scientific Achievement Award.

In his thirty-year career with the Canadian Forest Service, Brian Stocks

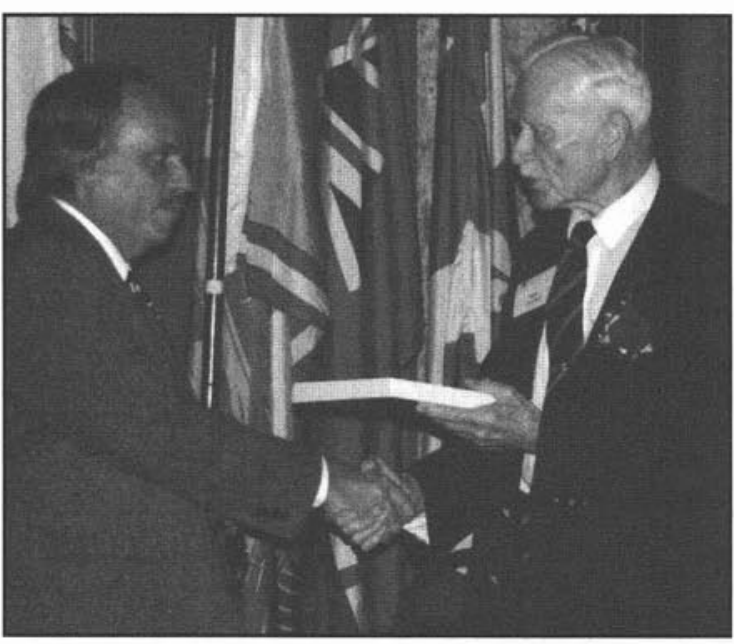

has been recognized nationally and internationally as a leader in the field of forest fire research. Mr. Stocks's field studies and experimental burning programs led to the development and improvement of the Canadian Forest Fire Weather Index System, and the Canadian Forest Fire Behaviour Prediction System, and components of the Canadian Forest Fire Danger Rating System (CFFDRS).

The CFFDRS is used universally by fire management agencies across Canada for daily tactical planning and directing fire suppression operations. It is a fundamental component of how those agencies do business. The CFFDRS has also been adopted by several of the United States for use in their fire operations.

Left, Herb Beall (R) presents the Canadian Forestry Scientific Achievement Award to Brian Stocks.

Right, Stephen Ginnish (L) receives the James M. Kitz Award from Ralph Roberts.
In the past decade, Mr. Stocks has worked with a large number of international research agencies on the behaviour, environmental and atmospheric impacts of forest fires on the global basis. This work is a major contribution to the study of global atmospheric. dynamics and the implications of fire and global climate change. The work has included experimental burning programs and field research across the world, including Siberia, South Africa, and Alaska. This work, including cooperators such as NASA, the United States Forest Service, and the United Nations, is critical to understanding the contribution of global biomass burning to the rate and impact of climate change, and to forecasting the potential implications of climate change to forest health and fire environment in Canada and other circumpolar countries.

He serves on many national and international committees such as the International Geosphere-Biosphere Program, The Global Change and Terrestrial Ecology Project, chair of the International Boreal Forest Research Association Fire Working Group. He is a member of the United Nations Team of Fire Specialists and is currently involved with the UN-Environment Program in assessing the Indonesian and Brazilian fire situations. $\mathrm{He}$ is also the Chair of the IUFOR Forest Fire Research Working Group. He has authored/co-authored over 110 scientific papers on many aspects of fire research. He has made significant contributions to knowledge, enhanced the practice of forest fire management and has played an important leadership role in the international scientific research community.

We are pleased to award Brian Stocks with the Canadian Forestry Scientific Achievement Award.

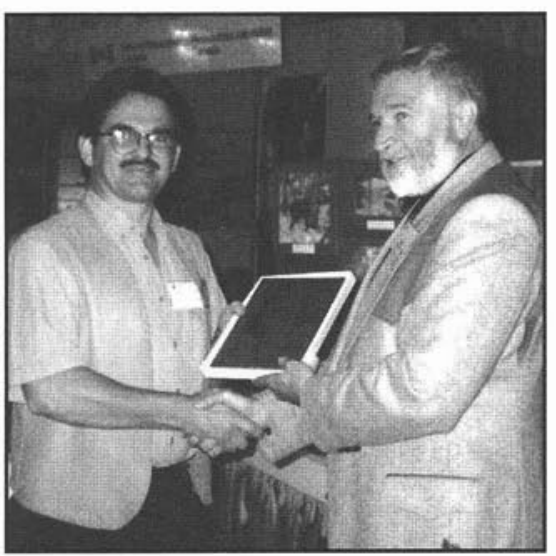




\section{James M. Kitz Award}

Most, if not all recipients of the CIF/IFC national awards are people who have earned these awards as a result of accomplishments over long and well established careers. The CIF/IFC recognized in 1994 that there are many younger people involved in forestry across Canada who are making outstanding contributions early in their profession and in 1995 created a new award to recognize the contributions of those newer to the profession.

The James M. Kitz Award is named after a person who was a member of CIF/IFC and the Alberta Registered Professional Foresters Association. Jim made several outstanding contributions to forestry early in his career, but suffered a sudden and untimely death at age 36 . This award recognized the contributions made by Jim, both professionally and personally and is awarded to those who exemplify Jim's approach to all aspects of life while making an outstanding contribution to forestry early in their career.

This year, we are honoured to award the James M. Kitz award to Mr. Stephen Ginnish. Mr. Ginnish has exceptional ability to bring people of various backgrounds together for the common good. Joe O'Neil stated in his letter of support "he builds bridges that last"; "he is a trusted and respected member of the forest community in the Maritime Region, and has very effectively represented the voice of Aboriginal People on a local, provincial and National level. Without question, Steve has made a major contribution in bringing the general community of Miramichi and First Nations people closer together for the common good. His kind, pleasant and enthusiastic attitude are a welcome addition to any New Brunswick project".

Mr. Ginnish has conducted a forest management program at the Eel Ground First National since 1989, which has greatly improved the condition of the resource through treatments such as residual removal and thinning while providing much needed employment on the reserve. He has ensured that members of the First Nation community were trained by the local community college in proper forest management treatments and these community members are now fully capable of working off reserve for industry or private woodlot owners. Mr. Ginnish oversees the run- ning of the community's portable sawmill, which obtains much of its supply from the residual removal treatments. He also provides advice and training to other First Nations, within New Brunswick, when starting a forest management program. He assisted in the filming of a video to promote the First Nations Forestry Program to First Nations across the country. He promotes the importance of protecting the environment to school children in Eel Ground through conducting sessions in the classrooms, and has conducted environmental rehabilitation projects such as the restoration of a shale-rock pit and the replacement of inad-

\section{Canadian Forestry Achievement Award}

The Canadian Forestry Achievement Award is awarded to an individual in recognition of outstanding achievement in Forestry in Canada.

We are honoured to provide the achievement award to Mr. Ted Boswell. Mr. Ted Boswell was nominated for the Canadian Forestry Achievement Award based on his unique and outstanding accomplishments in the forestry sector including his visionary leadership in the forest industry, sustainable forest management and research, the profession of forestry, forest education as well as contributing to community affairs.

Mr. Boswell graduated with his B.Sc.F from UNB and MBA from University of Western Ontario. Mr. Boswell has served in senior leadership roles with the forest industry as Chair of the Canadian Pulp and Paper Association and the Ontario Forest Industry Association and as Vice-Chair of the Council of Forest Industries, Canada. Mr. Boswell has contributed outstandingly to forestry development in the development of the CSA/ISO certification process for forest management to maintain market access for Canadian firms in offshore markets, where he was the driving force in establishing this process and moving ahead. $\mathrm{He}$ was involved in many negotiations with the Ontario Government on Forest Management Agreements to provide good forest management plus tenure for forest product producers. He was involved in the Canadian-U.S. Softwood Lumber negotiations where he was and continues to be a key player in protecting Canadian forestry interests.

Mr. Boswell has severed as a Director of the Pulp and Paper Research Institute, equate bridges across streams. $\mathrm{He}$ involves the elders in the decision making process with respect to the implementation of the forest management program at Eel Ground. Mr. Ginnish initiated a project to record the knowledge of the elders on medicinal plants and spiritual and cultural practices. He serves as a councilor for the Eel Ground First Nation with responsibility for forestry and the environment, he is a board member for the National Aboriginal Forestry Association.

It is with great pleasure to present the James M. Kitz award to Mr. Stephen Ginnish.

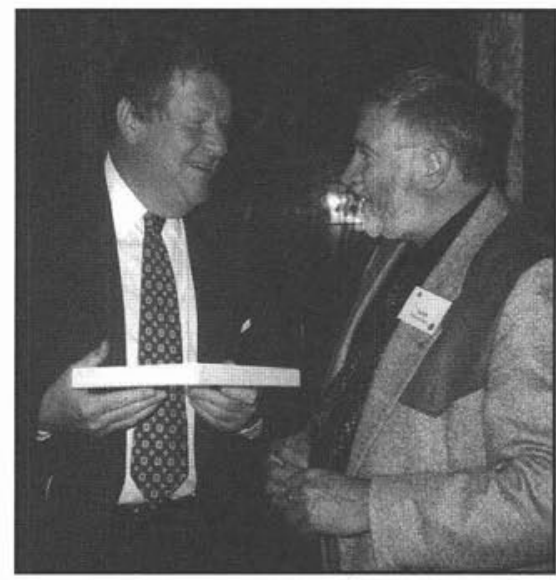

Ted Boswell receives the Canadian Forestry Achievement Award from Ralph Roberts.

Chair of the Forest Engineering Research Institute, and as a member of the Ontario Forestry Council. He was also Member of the Premier's Council of Ontario, the Round Table on the Environment and the Economy as well as the New Directions Group that included industrialists, environmentalists and academics that came together to contribute significant solutions to Canadian forestry issues. He is currently Vice-Chair of the Board of the Nature Conservancy of Canada. He has also served on Advisory Board of the Faculties of Forestry at U.B.C. and the University of Toronto and is currently a member of the Advisory Board of the Faculty of Forestry and Environmental Management at the University of New Brunswick.

$\mathrm{He}$ has traveled and given lectures worldwide.

It is with great pleasure that we award the Canadian Forestry Achievement Award to Mr. Ted Boswell. 


\section{Canadian Forestry Achievement Award}

We are pleased this year to award two Canadian Forestry Achievement Awards.

We are also pleased to present the Canadian Forestry Achievement Award to Mr. Dirk Brinkman. Mr. Brinkman completed his undergraduate studies in philosophy, mathematics and literature at Calvin College in Michigan and undertook graduate work in theology at Calvin and the Institute of Christian Studies in Toronto. During the summers while we was attending college, Mr. Brinkman worked on falling and slashing contracts. When his bid was accepted on one of the four trial reforestation contracts in 1970 , his forestry career was launched.

$\mathrm{He}$ incorporated his contracting business as Brinkman and Associates Reforestation Ltd., in 1979 and through strong financial and business management, he survived the seasonal and competitive nature of the reforestation business. Mr. Brinkman has expanded across the country and into a wide range of silviculture activities. Now employing up to a thousand seasonal workers, the company has planted over half a billion seedlings, spaced and girdled over twenty thousand hectares and brushes over three thousand hectares. The organization is also engaged in activities such as site preparation, cone picking and pest control.

By building strong working relationships with clients, several major forestry companies have used Brinkman's services for over twenty years. In the words of Mac Squire in his letter of support he stated "Dirk's consistency generates trust."

Mr. Brinkman has been a major innovator in silviculture. Silviculture was a new industry in the 1970s. Often by collaborating with manufactures, he developed many new pieces of equipment specifically for planting, such as planting hoedads, planter bags and shovels. To allow other planters to use these improved tools, he established Tree Planter's Grubstake and Silviculture Supplies in 1980.

Mr. Brinkman purchased two seedling nurseries in Ontario with a production capacity of twenty million seedlings annually. Here he initiated the "growplant" concept leading to contracts with major clients. He is a well-known and respected leader in reforestation. $\mathrm{He}$ was the driving force behind formation of Silviculture Industry Associations

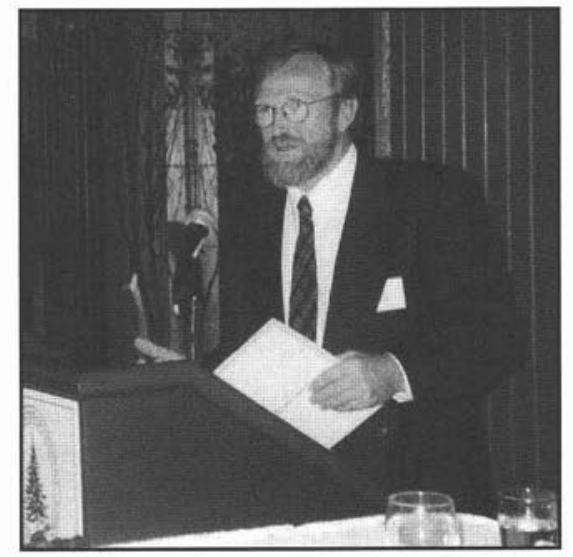

across Canada and was the President of the Canadian Silviculture Association between 1991 and 1997. He has participated on numerous provincial and national committees and taskforces addressing a range of forestry and reforestation issues. As a strong voice in the industry, for example, he lobbied suc-

\section{Canadian Forest Management Group Achievement Award}

Canadian Forest Management Group Achievement is awarded in recognition of outstanding achievement by teams and groups of Natural Resource managers, Researchers and NGO groups in the field of forest resources related activities in Canada.

This year is the first year of presenting this award, and we are pleased to present the award to Scouts Canada.

The Scout movement was founded in 1907 , and currently has 4,500 groups
Dirk Brinkman, recipient of the Canadian Forestry Achievement Award.

cessfully for "free-to-grow" legislation, and for the worker health regulations which are now integral to the B.C. Forest Practices Code and the Workers Compensation Board (WCB) Safety regulations.

In addition to being the founder, editor and publisher of the Canadian Silviculture Magazine and its forerunners, he has written and co-authored numerous articles and research studies.

Dirk is best described as an environmental entrepreneur. To further the interests of the world's forests, he has shown determination, business drive, leadership and a seemingly endless ability to identify and develop opportunities. It is will great pleasure that we present the Canadian Forestry Achievement Award to Mr. Dirk Brinkman.

across Canada with 240,000 youth and leaders involved. Scouts Canada plays a significant role in the education of Canada's youth with respect to our natural environment and its conservation and forest resource management. Scouting is a co-ed youth organization, which welcomes both male and female members in all sections. Scouts Canada in conjunction with various provincial government resource management agencies initiated a Canada-wide environmental

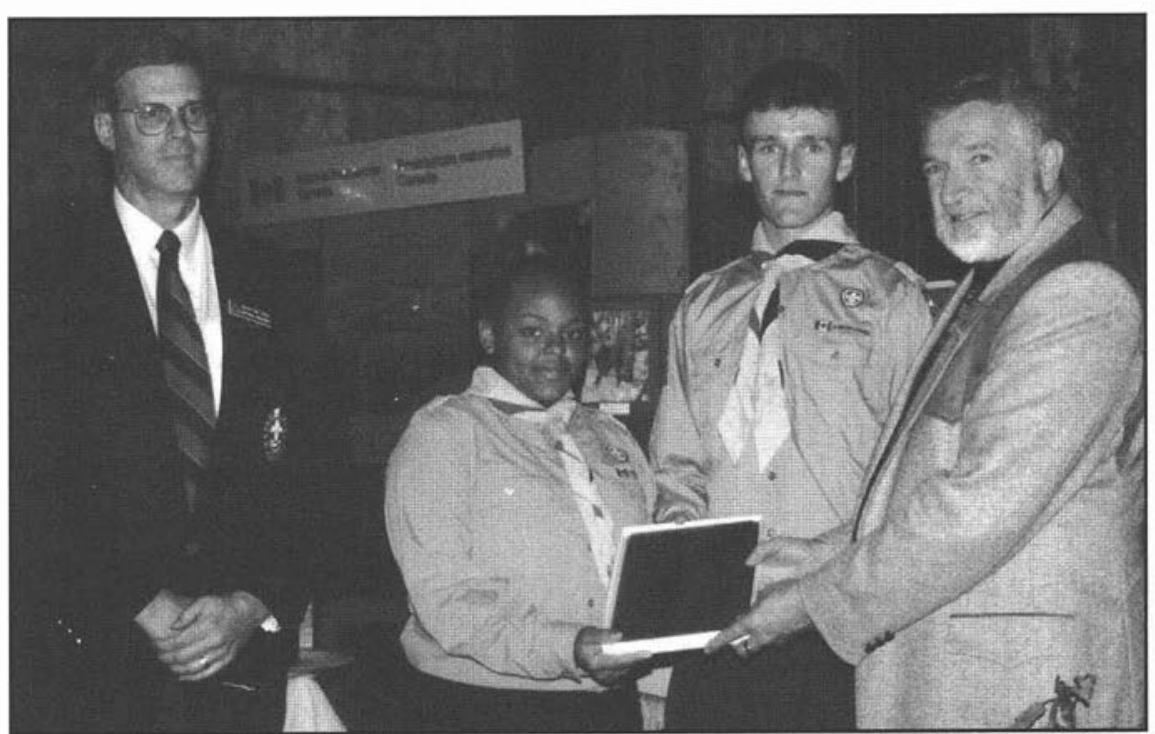




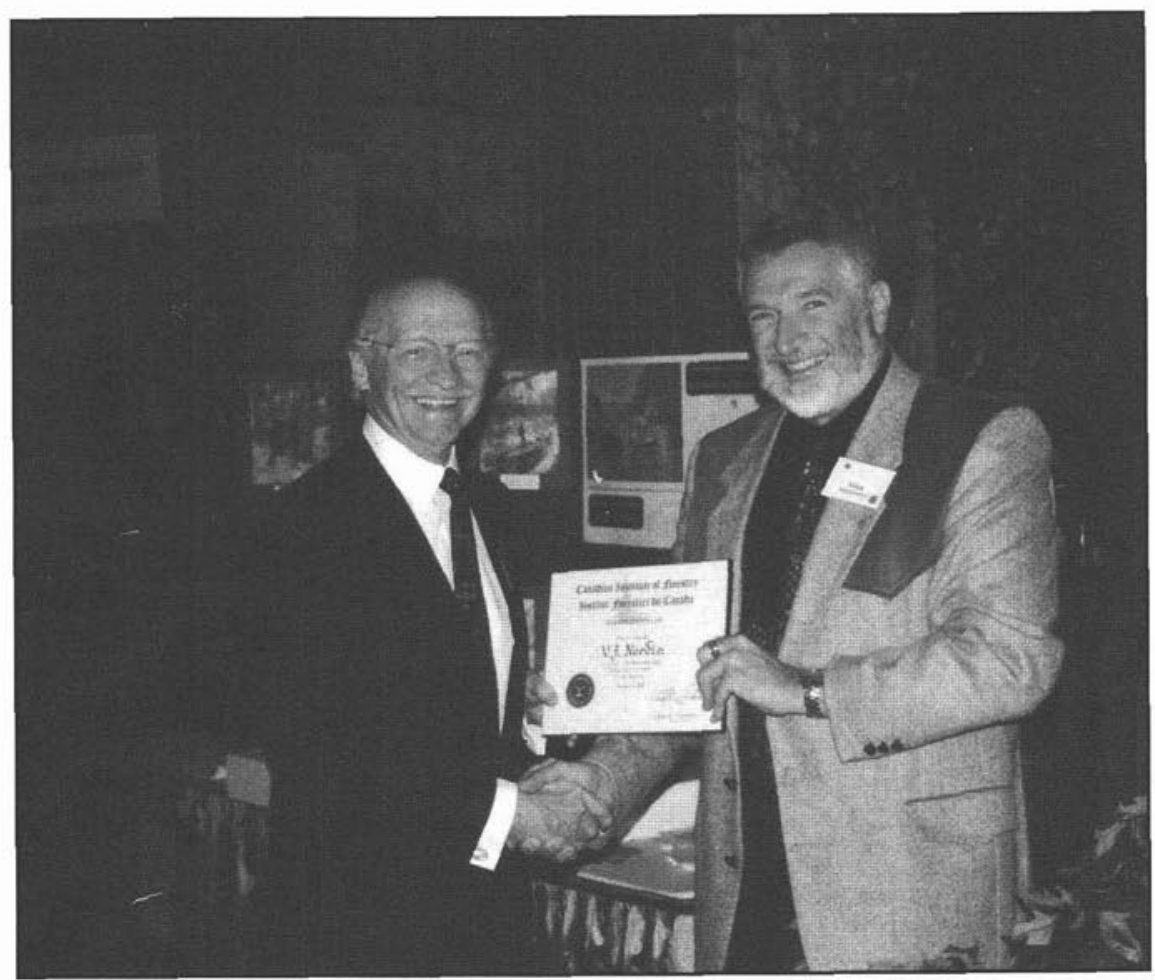

Vidar Nordin (L), Golden Year member.

Jim Cayford presents the Tree of Life Award to Bill Fullerton (L).

program in 1972 which focused on the importance of trees and forests to our urban, rural and wilderness landscapes. Since 1972 Scouts across Canada have planted in excess of 58 million trees. In 1998 Scouts planted 4 million trees in Canada.

In 1985, Scouts Canada was the first recipient of the World Environment Festival Award in recognition of the importance of Scout trees to the Canadian and global environment.

The Mission statement of Scouts Canada is to contribute to the development of young people in achieving their full physical, intellectual, social and spiritual potential as individuals as responsible citizens and as members of their local, national and international communities through the application of the Scouting Principles and Practices. We are pleased to provide this first presentation to Scouts Canada. Mr. Rattry, President of Scouts Canada and two Scouts are here to receive the award on behalf of Scouts Canada.

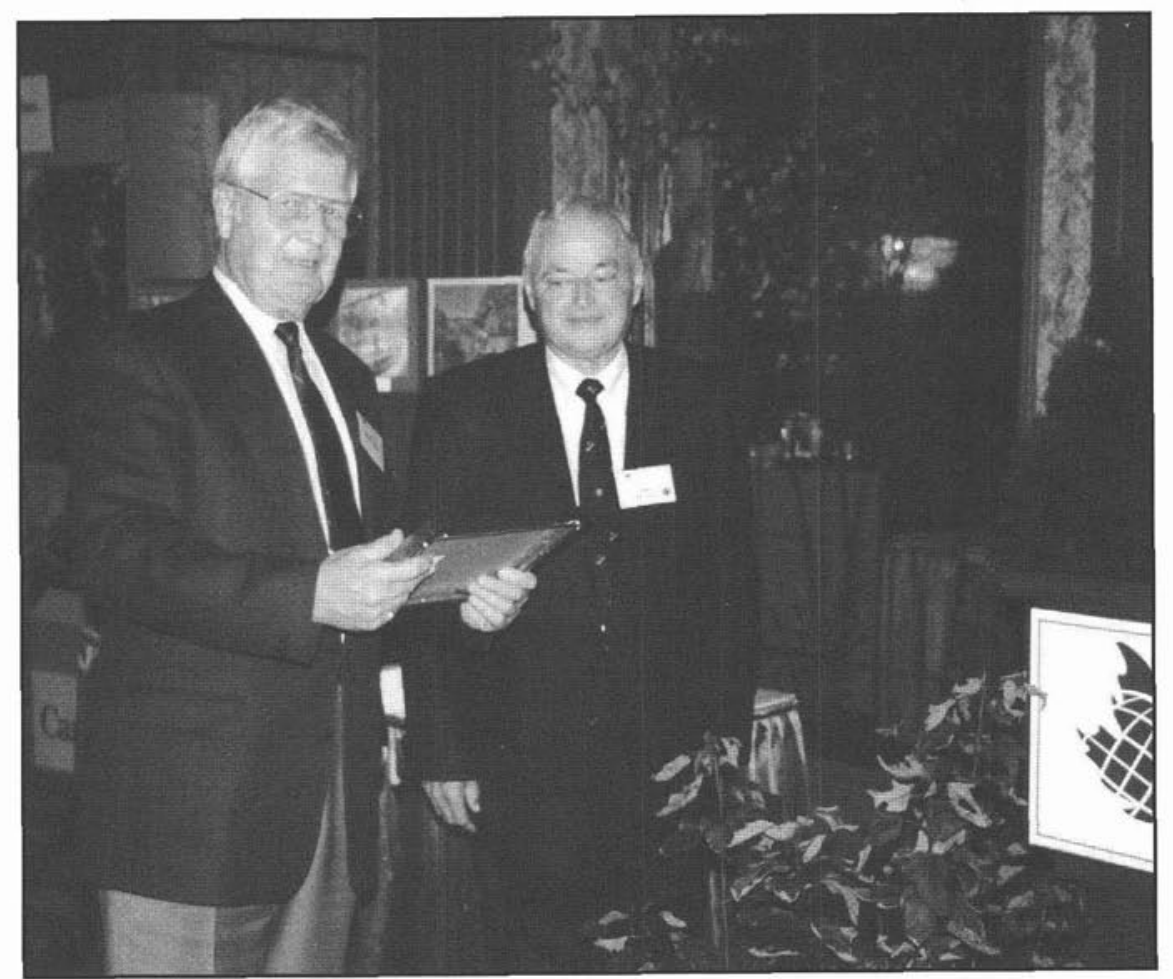

Left, Ralph Roberts presents Scouts Canada with the Canadian Forest Management Group Achievement Award. 


\section{Frank Oberle Sr. Awarded Honourary Member of the CIF/IFC}

The Canadian Institute of Forestry/Institut forestier du Canada is pleased to award Mr. Frank Oberle Senior with an Honourary Membership in the Institute. Mr. Oberle, Sr. was first elected as a member of Parliament in the riding of Prince George - River in 1972. He began his political career ten years earlier as Alderman and Mayor of Chetwynd, $\mathrm{BC}$, a community where he was active in both the Chamber of Commerce and the Hospital Board.

In Parliament he served on several committees and pursued his interests in Regional Economic Development, Northern Development, Natural Resources, and Indian Affairs.

However, his special interest has always been forestry. With forestry roots in his native Germany, he worked as a logger on the Queen Charlotte Islands after his arrival in Canada at the age of 19 . He also operated a sawmill and a ranch when he later moved to Chetwynd giving him a keen understanding of the sector.

In 1983, Mr. Oberle wrote his major report on forestry, entitled, The Green Ghetto. In it he outlined the importance of forestry to Canada, described decreases in productive forests through lack of regeneration, insects and disease, fire, acid rain and other losses. He described the need for intensive forestry, outlined the role of governments and drafted a detailed description of what the federal government should be doing in forestry including the creation of a full and separate forestry department. That list of federal activities went on to become the forestry platform of the Conservative Party of Canada in the 1984 election campaign. In 1989, when he was named Minister of Forestry, he built on the work initiated by Gerry Merrithew and set about to bring the Canadian Council of Forest Ministers to its fullest potential. As Minister of Forests, he saw the drafting and passing of the legislation that created Forestry Canada. He included the requirement that an Annual Report to Parliament be prepared for government and the people of Canada. Its release is still today a major event in Ottawa and across the country.

One of the efforts that Mr. Oberle championed was the review and revision of the 1987 National Forest Sector Strategy. He recognized that much had changed in forestry in the late 1980 s and that a new national Strategy was needed. Through his efforts as Chairman of CCFM, a nation wide process of consultation was begun. In addition, a Canada Forest Accord was drafted. This Accord describes the importance of our forests, outlines the beliefs and visions of Canadians and commits the signatories to action. It was a significant event for forestry in Canada. Since that Strategy, two more Strategies have been developed

\section{Dr. Roy Sutton Awarded Fellow in the Canadian Institute of Forestry}

The Canadian Institute of Forestry/Institut forestier du Canada is honoured to recognize Roy F. Sutton as Fellow of the CIF. Dr. Sutton is being recognized for his work in white spruce, particularly in the establishment years, and for his contributions to the Canadian Institute of Forestry.

Dr. Sutton was born in Stourbridge, Worcestershire, England in 1926. He served in the Royal Corps of Signals of the British Army from 1944 to 1948 in the United Kingdom, India, Ceylon (now Shri Lanka), Singapore and Hong Kong. He graduated with a B.Sc. from Edinburgh University in 1955 and emigrated to Canada the following year on a Beaverbrook post-graduate fellowship. He joined the Forestry Branch of the Department of Northern Affairs and Natural Resources that year and started on his M.Sc. at the University of New Brunswick, graduating in 1957 . He worked for the Forest Management Institute in Richmond Hill, Ontario before taking a leave of absence to complete his Ph.D. at Cornell University in 1968. His thesis was titled "Ecology of young white spruce (Picea glauca [Moench] Voss)." He rejoined the Department in Sault Ste. Marie where he completed his distinguished career with the Canadian Forest Service.

During his nearly four-decade career in forestry research, Dr. Sutton became a well-known authority on tree establishment from a biological perspective. His exhaustive work on white spruce check gained him early recognition, as did his investigations of seedling root system morphology and his insistence on planting stock quality. While Dr. Sutton is especially identified with white spruce, his interests, particularly in later years, and Accords have been signed, the most recent in March of 1998 in Ottawa, setting the stage for the next five years.

Mr. Oberle has been an active member in the forestry community since his retirement. He takes a sincere and keen interest in the forest community work.

CIF/IFC Honourary Membership is awarded to non-members of the Institute who have made outstanding contributions to the advancement of forestry.

extended to other boreal conifers as well. The appropriate use of chemical herbicides in stand establishment, deep planting, and mounding also figure heavily in his research. Dr. Sutton's personal research and development work is documented in his many scientific and technical publications. As well, reflecting his stature on the world stage, he has authored numerous authoritative reviews as well. Dr. Sutton was a longtime Senior Scientist, Silviculture, at the Great Lakes Forestry Centre, Sault Ste. Marie, ON, where he nurtured and guided a whole new generation of forest scientists. Despite official retirement, Roy never truly retired - he now occupies a position of Scientist Emeritus at the Great Lakes Forestry Centre.

Roy has been a member of the Canadian Institute of Forestry for many years and was Book Review Editor for The Forestry Chronicle from 1971 to December 1991. He continues to review books for The Forestry Chronicle. His approach to book reviews has set a standard for reviewing that remains to this day. He was a recipient of a Special Award for his services to the Institute in 1985 . He has received other honours recognizing his professional work at the Great Lakes Forestry Centre. Roy has remained active with the Central Ontario Section, attending many meetings and technical workshops. He is a member of a variety of other Institutes and Societies, both professional and personal.

Roy is married to Maria, and has two children, Penelope and Patience, and continues to live in Sault Ste. Marie. His hobbies extend to music, books, photography, rocks, minerals and brass rubbings. 